\title{
The Vulnerability of Conscience: The Constitutional Basis for Protecting Religious Conduct
}

\author{
Christopher L. Eisgruber $\dagger$ \\ Lawrence G. Sager††
}

\section{INTROdUCTION: THE PROBLEMATIC Status OF RELIGIOUS EXEMPTIONS}

In Employment Division, Department of Human Resources of Oregon $v$ Smith, the Supreme Court held that members of the Native American Church were not constitutionally entitled to ingest peyote as part of their religion's sacrament in the face of an Oregon law outlawing the use of peyote. ${ }^{1}$ Many aspects of the Smith decision have been sharply criticized, but none so much as the general view of religious exemptions announced by Justice Scalia's opinion for the Court. Justice Scalia distinguished freedom of religious belief from behavior driven by religious belief, and further distinguished laws directed at religion from general laws that merely collide with behavior driven by religious belief. That work done, Justice Scalia had a simple and flat response to the constitutional claimants in Smith: religious believers have no constitutional license to disregard otherwise-valid general laws that conflict with the dictates of their religion. ${ }^{2}$

Smith sharply divided the Court on the question of extant doctrine as to the constitutional status of religious exemptions. Four of the justices-Justice O'Connor, who concurred in the

$\dagger$ Associate Professor of Law, New York University School of Law.

it Professor of Law, New York University School of Law. For helpful comments on previous drafts of this essay, the authors wish to thank Akhil Amar, Ronald Dworkin, Jim Fleming, Abner Greene, David Richards, and the participants in faculty workshops at the Boston University Law School Faculty Workshop and the New York University Constitutional Theory Colloquium. The authors also wish to thank the Filomen D'Agostino and Max E. Greenberg Faculty Research Fund at the New York University of School of Law, which provided generous financial support for this project.

An important theme of this essay is that religion does not exhaust the commitments and passions that move human beings in deep and valuable ways. For us, the finest reminder of this idea is the special place of Lori Martin and Jane Cohen in our respective lives, and we accordingly dedicate this essay to them.

1494 US 872,890 (1990).

2 Id at $877-80$. 
outcome only, and the three dissenting justices-were outraged at what they saw as the Court's startling and unwarranted departure from settled doctrine. In their view, it had become a commonplace of constitutional doctrine that only governmental interests of "the highest order" could justify a state's interference with religiously driven behavior. Justice Scalia and his colleagues in the majority saw matters very differently; for them, the idea that religious motivation could exempt one from the reach of an otherwise valid general law was wholly novel and out of step with constitutional law and the rule of law generally. ${ }^{4}$

Actually, neither of these characterizations of constitutional law ante-Smith was fair or convincing. Doctrine governing religious exemptions was in a shambles. In a small but durable line of cases involving the entitlement to unemployment benefits of persons whose religious scruples prevented them from working on Saturday (Sherbert $v$ Verner $^{5}$ and its progeny) or from manufacturing armaments, ${ }^{6}$ the Court had consistently held that the state could put people to a choice between their consciences and material disadvantage only if its reasons for doing so were markedly weighty. But only in one case outside of Sherbert $v$ Verner and its unemployment benefits progeny had the Court actually appeared to act on that principle: in Wisconsin $v$ Yoder, it held that Wisconsin's stake in requiring all children to pursue a recognized program of education until the age of sixteen was not sufficient to justify the state's interference with the religiously motivated commitment of the Amish to integrate children into their working society at the age of fourteen. ${ }^{7}$ Everywhere else there were strong indications that the Court could not in fact live with the broad dictum of Sherbert.

In Reynolds $v$ United States, it should be remembered, the Court rejected not only the claim of the Mormons to a constitutional right to practice polygamy; it also rejected as unthinkable the idea of each religious believer creating a microenvironment of law molded to her separate beliefs. ${ }^{8}$ The cases that mediated between Reynolds and Sherbert half a century later-notably

3 Id at 892 (O'Connor concurring); id at 907-08 (Blackmun dissenting).

4 Id at 879.

- 374 US 398 (1963). See also Hobbie $v$ Unemployment Appeals Commission of Florida, 480 US 136 (1987).

T Thomas $v$ Review Board of the Indiana Employment Security Division, 450 US 707 (1981).

7406 US 205, 207, 234, 236 (1972).

898 US 145, 166-67 (1898). 
West Virginia State Board of Education v Barnette ${ }^{9}$ and Cantwell $v$ Connecticut ${ }^{10}$-were certainly more sympathetic to religion generally, but they were so fully wrapped with issues of free expression as to deflect rather than answer the concern that animated the Court in Reynolds.

In the Court's more modern experience, the Sherbert line and Yoder emerge as exceptions rather than the rule: in some cases since Yoder and outside the unemployment benefits area, the Court has paid lip service to the Sherbert rule, but in each of these cases it has found the compelling state interest test of Sherbert satisfied. ${ }^{11}$ While in other constitutional areas the compelling state interest test is fairly characterized as 'strict' in theory and fatal in fact," ${ }^{\prime 2}$ in the religion cases the test is strict in theory but feeble in fact. ${ }^{13}$ Furthermore, even before Smith, the Court had begun to find reasons for rejecting the Sherbert formulation altogether in particular exemption contexts. ${ }^{14}$

A candid assessment of the corpus of case law confronting the Court in Smith would have emphasized disarray, not order. And Smith itself, unhappily, did nothing to improve the situa-

319 US 624 (1943).

10310 US 296 (1940).

11 See Bob Jones University v United States, 461 US 574, 604 (1983) (government interest in eradicating discrimination in education); United States $v$ Lee, 455 US 252, 260 (1982) (government interest in preserving a sound tax system); Johnson $v$ Robison, 415 US 361, 385-86 (1974) (government interest in raising and supporting armies). In other cases, the Court has rejected Free Exercise claims on the ground that the challenged practice imposed no actual burden upon the religious convictions of the claimants. See, for example, Lyng v Northwest Indian Cemetery Protection Ass'n, 485 US 439, 448-49 (1988) (building road over sacred areas did not burden religious belief); Bowen $v$ Roy, 476 US 693, 700 (1986) (requiring disclosure of a social security number for welfare benefits did not burden religious beliefs); Alamo Foundation v Secretary of Labor, 471 US 290, 304-05 (1985) (imposing a minimum wage requirement does not burden religious believers who refuse, for religious reasons, to accept wages).

12 The phrase belongs to Gerald Gunther, The Supreme Court, 1971 Term-Foreword: In Search of Evolving Doctrine on a Changing Court: A Model for a Newer Equal Protection, 86 Harv L Rev 1, 8 (1972).

${ }^{13}$ Ira Lupu, remarking upon the same point, calls the Free Exercise compelling state interest test "strict in theory, but ever-so-gentle in fact." Ira C. Lupu, The Trouble With Accommodation, 60 Geo Wash L Rev 743, 756 (1992). See also Robert D. Kamenshine, Scrapping Strict Review in Free Exercise Cases, 4 Const Comm 147, 149 (1987) (noting the inconsistency between the Court's rhetoric and its practice).

${ }^{34}$ See, for example, O'Lone $v$ Estate of Shabazz, 482 US 342 (1987) (compelling interest analysis not applicable to prison regulations); Bowen, 476 US at 708 (Burger plurality) (when a challenged statute merely regulates the availability of government benefits, neutral and uniform rules that burden religious beliefs are constitutional so long as they are a reasonable means to promote a legitimate government interest); Goldman $v$ Weinberger, 475 US 503, 506-07 (1986) (compelling interest analysis not applicable to military regulations). 
tion. Neither the majority nor the dissenting positions in Smith offered a view of the exemption problem that can at once explain the distinct status of religion in our constitutional tradition, offer a workable and attractive approach to the exemption issue, and make more or less good sense out of the scattered pattern of precedent.

What is needed is a fresh start. We need to abandon the idea that it is the unique value of religious practices that sometimes entitles them to constitutional attention. What properly motivates constitutional solicitude for religious practices is their distinct vulnerability to discrimination, not their distinct value; and what is called for, in turn, is protection against discrimination, not privilege against legitimate governmental concerns. When we have replaced value with vulnerability, and the paradigm of privilege with that of protection, then it will be possible both to make sense of our constitutional past in this area and to chart an appealing constitutional future.

That is the project of this Article. We hope to demonstrate that the privilege view of religious exemptions is normatively unjustified and unattractive in its practical implications, while the protection view is both justified and attractive in its consequences.

Groups will figure at several points in our discussion. The predominance of groups in religious practice is important to the understanding of both privilege and protection. Religious groups are in some respects uncontroversially secure from the reach of state command. For example, however committed we may be to gender and racial equality, most of us do not imagine that the state can tell a religious group that it must be indifferent to gender or race in its choice of spiritual leaders. ${ }^{15}$ This aspect of our constitutional tradition may seem to support the idea that religion is constitutionally privileged. Yet religion has no monopoly on barriers limiting the reach of state authority. We do not imagine that the state could insist on gender or racial neutrality in an individual's choice of her psychiatrist, lawyer, or intimate friends. What makes religious practice distinct for these purposes is not its value, but rather its structure: religion often involves the extensive, communal enactment of behavior and relationships

15 The view is not held unanimously. See Ira C. Lupu, Free Exercise Exemption and Religious Institutions: The Case of Employment Discrimination, 67 BU L Rev 391, 439-40 (1987) (suggesting that churches that admit women to their congregation may be compelled to admit women to their priesthood). 
of the sort that ordinarily take place in far more cloistered, personal contexts.

While the group aspect of religious practice thus may produce false signs of constitutional privilege, it is a genuine element in the cultural dynamic that produces the need for constitutional protection. The solidarity and insularity of group membership and belief sustain the insistence of many religions on one right God and one right way to homage and salvation-upon one right and insular epistemology. It is the group identity of the faithful that mobilizes pity, distrust, or even hatred for those who are not believers.

Although we will ultimately return to offer some brief reflections on the relationship between religion and group rights, our path to those conjectures will travel almost entirely through territory dedicated to the problem of exemptions for religiously motivated conduct. ${ }^{16}$ That issue has recently taken on new significance. It is now apparent that Smith will not be the Court's last word on this issue. Perhaps that was evident from the start, for the Smith Court did more to underscore the disarray surrounding the issue than it did to resolve any of the difficulties arising from the clash between collective authority and individual religious conscience. Recently, however, Congress's response to Smith has further complicated matters. The President has signed into law the Religious Freedom Restoration Act of $1993,{ }^{17}$ which passed

16 Articles on this topic are, we admit, legion. Distinguished contributions to the literature before Smith include: John H. Garvey, Free Exercise and the Values of Religious Liberty, 18 Conn L Rev 779 (1986); Lupu, 67 BU L Rev 391 (cited in note 15); Ira C. Lupu, Where Rights Begin: The Problem of Burdens on the Free Exercise of Religion, 102 Harv L Rev 933 (1989); Michael W. McConnell, Accommodation of Religion, 1985 S Ct Rev 1; and Mark Tushnet, The Emerging Principle of Accommodation of Religion (Dubitante), 76 Georgetown L J 1691 (1988). Smith precipitated a torrent of articles, virtually all of them critical of the Court's ruling. A limited sampling of these essays includes: James D. Gordon III, Free Exercise on the Mountaintop, 79 Cal L Rev 91 (1991); Abner S. Greene, The Political Balance of the Religion Clauses, 102 Yale L J 1611 (1993); Ira C. Lupu, Reconstructing the Establishment Clause: The Case Against Discretionary Accommodation of Religion, 140 U Pa L Rev 555 (1991); Michael W. McConnell, Free Exercise Revisionism and the Smith Decision, 57 U Chi L Rev 1109 (1990); William P. Marshall, In Defense of Smith and Free Exercise Revisionism, 58 U Chi L Rev 308 (1991); Douglas Laycock, The Remnants of Free Exercise, $1990 \mathrm{~S}$ Ct Rev 1; and a superb student work by James Ryan, Note, Smith and the Religious Freedom Restoration Act: An Iconoclastic Assessment, $78 \mathrm{Va}$ L Rev 1407 (1992). Despite all this scholarly attention, much remains to be said about the exemptions problem. Of the works cited, only Marshall's directly challenges the assumption that religion enjoys a constitutional privilege. This Article's attempt to construct a protection theory of religion's constitutional status is, so far as we know, unique.

17 Pub L No 103-141, 107 Stat 1488 (1993), codified at 42 USCA $\S 2000$ bb (Supp 1994). 
both houses of Congress by overwhelming majorities. ${ }^{18}$ Essential$\mathrm{ly}$, the Act seeks to restore the status quo ante-Smith by subjecting laws that interfere with an individual's conformity to religious mandate to the compelling state interest test. The Act raises a variety of questions, not the least of which is how the Court ought to respond to a congressional mandate predicated on an infirm view of the state of constitutional law prior to the decision in Smith. Before we can either assess the wisdom of the Act, or try to imagine how the Court ought to respond to its problematically framed mandate, we need to begin with the more basic question of what the appropriate judicial response to constitutional claims for religious exemptions ought to be.

\section{Two Modalities of Constitutional Justice: PRIVILEGE AND PROTECTION}

The vigorous pursuit of political justice in modern constitutional law has two great paradigms: the right of free expression and the right of African Americans to equal protection. These two traditions have dominated our modern constitutional sensibility, and discourse about the propriety of vigorous judicial intervention on behalf of other values often proceeds by way of comparison to them. There is a structural difference between these two pillars of constitutional justice, and understanding that difference illuminates the claim that religion makes on our constitutional judgments.

We have in mind the difference between the Constitution's privileging persons or practices and the Constitution's protecting such persons or practices. Speech is a practice that is privileged in our constitutional tradition, indeed privileged to a high degree. The state is often barred from restricting speech because of its content, even when there is reason to suppose that important concerns would be advanced if the speech in question were suppressed. In contrast, African Americans are not privileged, but rather protected. Constitutional law struggles to abolish caste and its residue, to secure for African Americans treatment as full and equal citizens of our national community.

In our constitutional tradition, a claimant who locates her behavior within the core of protected speech activity acquires the privilege of immunity from the reach of governmental authority, even under circumstances that would otherwise offer strong

18 See 139 Cong Rec H 2356-03 (May 11, 1993); 139 Cong Rec S 14471 (Oct 27, 1993). 
grounds for the exercise of that authority against her. She may act in a fashion that increases the likelihood that injuries to the property or persons of others may take place; ${ }^{19}$ she may act in a fashion that is itself injurious to others; she may even and especially act in a fashion that is injurious to the national interest as it is presently conceived. Her behavior is privileged, as against other behavior that shares these abstract features, and as against the interests of those persons who may be injured by that behavior. ${ }^{20}$

A claimant who argues for exemption from the reach of state authority on grounds of racial equality stands in a different posture. She is insisting on parity, not advantage: she demands that the state behave in a fashion fully consistent with her status as an equal citizen, as opposed to treating her as a member of a subordinate class who by virtue of that membership does not enjoy the same concern and respect. She invokes the Constitution against subordination. She is asking for something that is in principle the due of every member of our political community. Her racial status is constitutionally distinct in the sense that it marks her as vulnerable to injustice, to treatment as other than an equal; her claim is for protection from that injustice.

Speech and racial equality are thus both treated distinctly and favorably by virtue of their inclusion in the agenda of judicial enforcement of the Constitution, while other claims of political justice-most prominently those diverse claims we lump into the broad category of "economic rights"-are excluded. But only speech is privileged by the substance of the norms upon which the constitutional judiciary draws when it acts. Put another way, privilege and protection refer not to the fact of constitutional (or judicial) priority, but to the grounds for such priority. A claim for constitutional privilege requires a showing of virtue or precedence, while a claim for constitutional protection requires a showing of vulnerability or victimization. The distinction between privilege and protection is therefore ultimately a distinction in

19 See Brandenburg $v$ Ohio, 395 US 444 (1969).

20 The observation that speech is privileged need not take any specific position among the possible understandings of the structure of that privilege. The best account of constitutional justice, for example, might treat the ambition of securing an appropriate regime of public discourse as lexically prior to other concerns of the state; alternatively, it might treat that ambition as one entitled to special weight in an all-things-considered judgment. In all probability, both of these metaphorical characterizations of the nature of speech's privilege are radically oversimplified as against a more nuanced picture that is domain specific. But the point is that the idea of privilege encompasses all of these meanings. 
constitutional objective. From the recognition of victimization, and of vulnerability to future victimization, flows the constitutional objective of protection; while from the recognition of virtue or precedence flows the constitutional objective of privilege.

The distinction between privilege and protection in constitutional justice cannot always be read from the surface of the rules employed by courts to protect constitutional principles: the compelling state interest test, for example, figures in both speech and racial equality doctrine. But beneath the facial rules of constitutional law, at the level of constitutional justice, the justification for distinct constitutional treatment and the appropriate scope of that treatment are different if the claim is one of privilege or one of protection. ${ }^{21}$

In our constitutional jurisprudence there is no privileging of persons; indeed, opposing caste or subordination is one of the most robust projects of modern constitutional law. One might think that the converse is also true: because protection flows from a concern about vulnerability or victimization, it might seem that only persons or groups, rather than activities, may be the object of constitutional protection. But as religion itself vividly illustrates, individual and group identity can be defined by shared commitments and practices. More to the immediate point, persons and groups can be vulnerable to victimization by virtue of their shared commitments and practices. The bitter divisions of humanity along religious lines, and the global persecution of religious minorities throughout most of recorded history, make the victims of religious intolerance the ultimate and tragic exemplars of vulnerability.

Nevertheless, most modern commentary has proceeded on the assumption that the constitutional status of religious exemptions rises or falls on the degree to which religious practices are

${ }^{21}$ The priority of conflicting principles of constitutional justice does not turn on their affiliation with privilege or protection. Thus, to observe that constitutional principle $X$ is founded on privilege, while constitutional principle $Y$ is founded on protection, is not to offer a view about how a conflict between these two principles ought to be resolved.

The distinction does not tidily map-as might first appear-onto the conventional categories of liberty concerns and equality concerns. At the heart of speech doctrine is a premise of viewpoint neutrality that sounds in equality rather than maximizing speech opportunity, hence the great divide between viewpoint-specific regulations, which are highly disfavored in our constitutional tradition, and time-place-and-manner regulations, which despite occasional lapses of judicial rhetoric are widely tolerated. More deeply, the best accounts of constitutional protection of speech may well depend largely on the connection between free expression and the fair disposition of conflicting interests and viewpoints among political equals. 
constitutionally privileged-privileged in the way, for example, that speech is privileged. If religiously motivated people are to be exempt from the application of laws that they would otherwise be required to obey, it is assumed, this must be because religion is esteemed by the Constitution in a way that most other human commitments, however intense or laudable, are not. ${ }^{22}$

Indeed, though sharply divided in all other respects, the majority and minority factions in $S$ mith ${ }^{23}$ tacitly agreed that arguments about religious exemptions should turn on concerns of privilege. The argument in Smith thus assumed an all-or-practically-nothing form, with two losing sides. Consider the view of the minority: anytime the otherwise valid, general laws of the state collide with significant religious obligations, the religious obligations prevail unless the law in question can be shown necessary to achieving a compelling state interest. ${ }^{24}$ This is the same presumptive invalidity that attaches to laws that make facial distinctions adverse to racial minorities and to laws that imperil concerns close to the core of free expression. In the words of Justice O'Connor, the minority view of religious privilege was as strong as the majority view was barren:

The compelling interest test effectuates the First Amendment's command that religious liberty is an independent liberty, that it occupies a preferred position, and that the Court will not permit encroachments upon this liberty, whether direct or indirect, unless required by clear and compelling governmental interests "of the highest order."

22 An important exception is William Marshall, who denies that religion enjoys any constitutional privilege. See, for example, Marshall, $58 \mathrm{U}$ Chi L Rev at 320-21 (cited in note 16) (" $[R]$ eligious belief cannot be qualitatively distinguished from other belief systems in a way that justifies special constitutional consideration."). Marshall's view of the proper scope of constitutional-priority protection for religion may be narrower than the one we advance here. See, for example, William P. Marshall, The Case Against the Constitutionally Compelled Free Exercise Exemption, 40 Case W Res I Rev 357, 360-61 (1989-90) (arguing that the Free Speech Clause limits the scope of constitutionally compelled accommodations). Our argument, which embraces the principle we call "equal regard," preserves a distinct set of exemptions that protect, without privileging, religious belief.

${ }^{23}$ Smith yielded three opinions: a five-Justice majority opinion by Justice Scalia, a concurring opinion by Justice O'Connor, and a three-Justice dissent written by Justice Blackmun. We are including Justice O'Connor in the "minority" for these purposes because the doctrinal and analytical foundations of her concurring opinion are fully aligned with those of the dissenting Justices. ing).

${ }^{24}$ Smith, 494 US at 893-95 (O'Connor concurring); Id at 908-09 (Blackmun dissent-

${ }^{25}$ Id at 895 (O'Connor concurring), quoting Yoder, 406 US at 215. 
Much more needs to be said before we can fully respond to this view, but for the moment, the majority's unease is understandable: in a world and a country of great religious diversity, the faithful are invited to replace the collective self-rule of democracy with individual self-rule whenever their religious consciences direct them to do so, unless the collective authority of the state is founded on the bedrock of critical interests of "the highest order."

The majority view was no more appealing. For the majority, the distinct constitutional status of religion rather mysteriously runs out once the state frames its laws in terms of general application. ${ }^{26}$ Explicit religious tests, and direct, intentional intervention in the circumstances of worship, continue to be strongly resisted, but there the sharp constitutional concerns for religion come to a stop. On the majority account, even the Sherbert line seems imperiled, or at very best relegated to an exceptional category more or less hand-tailored to unemployment insurance cases. ${ }^{27}$

The inability of either faction of the Smith Court to arrive at an attractive and persuasive view of the exemption problem suggests that the paradigm of privilege itself is deeply misdirecting as a guide to religious liberty in general, and to the problem of religious exemptions in particular. A closer look at the privileging view strongly confirms this initial assessment.

\section{The Case against the Privileging VIEW OF RELIGIOUS EXEMPTIONS}

\section{A. The Privileging of Religion Made More Precise: Unimpaired Flourishing}

The underlying logic of the privileging view of religious exemptions is this: It is a matter of constitutional regret whenever government prevents or discourages persons from honoring their religious commitments; accordingly, government should act so as to avoid placing religious believers at a substantial disadvantage by virtue of their efforts to conform their conduct to their beliefs. This is the principle of unimpaired flourishing.

The principle of unimpaired flourishing is at the heart of the minority Justices' view in Smith, where it sponsored Justice O'Connor's ringing announcement that only governmental inter- 
ests "of the highest order" could justify interference with religiously motivated conduct. ${ }^{28}$ It is also common to the discourse of those commentators who argue for generous religious exemptions. Michael McConnell, for example, holds that "[ $t]$ he purpose of free exercise exemptions is to ensure that incentives to practice a religion are not adversely affected by government action." 29

Unimpaired flourishing is sometimes offered as a principle of equity, as though it functions merely to make those who respond to the strong demands of their religious beliefs no worse off than others. But unimpaired flourishing is different than that: it privileges religious commitments over other deep commitments that persons have. Members of our political community are not generally entitled to governmental arrangements that enable them to honor their important commitments without being placed at a substantial disadvantage. If somebody-say, Vincent-is above all committed to his art, and consumes his waking hours in devoted concentration to creating art, he is behaving in a manner that many would approve. Vincent is not, however, entitled in principle to arrangements that spare him the diverse costs of this behavior: Vincent is not entitled to an economic structure that permits him to prosper; Vincent is not entitled to collect unemployment insurance if he is by virtue of his passion unavailable for work; Vincent is not entitled to consume peyote even if, like Coleridge, he does his best work in an altered state of consciousness; Vincent is not entitled to bring toxic paints vital to the full realization of his artistic vision into his locality in the face of local environmental laws prohibiting their possession and use.

We may believe that some personal commitments deserve special support, of course, like a parent's decision to remain at home with a newborn child for the first several months. This means we believe that child care under these circumstances should be privileged as against other commitments (as a matter of sound legislative judgment rather than constitutional dictate). Thus unimpaired flourishing, transposed to this context, would require fully paid parental leave. That is just the point. Unimpaired flourishing is a privileging principle-providing certain parents a benefit because they decide to remain home for a socially preferred reason, rather than for some other reason-even though it only leaves its beneficiary no worse off by virtue of engaging in the privileged conduct.

28 Id at 895 (O'Connor concurring).

29 McConnell, $57 \mathrm{U}$ Chi L Rev at 1146 (cited in note 16). 
We have selected unimpaired flourishing to represent the privilege view of religious freedom because it captures the normative essence of the positions advanced by the most thoughtful partisans of a robust view of religious exemptions. In our discussion, however, little will turn on this precise formulation. Most if not all privilege views have this in common with unimpaired flourishing: they regard state interference with the observance of religious commandments as a constitutional vice that the state must avoid whenever it can do so without imperiling its most basic goals and obligations. Our evaluation of unimpaired flourishing will apply more or less in full to any formulation that shares this conceptual ground.

\section{B. Unimpaired Flourishing Applied}

Welfare-driven measures of justice have an endemic normative burden: idiosyncracies in the welfare functions of some individuals will support extreme and intuitively discreditable demands on social resources on their behalf-demands that seem to contradict the underlying project of securing justice. Thus utilitarians have to contend with the theoretical possibility of "welfare monsters," whose joyous consumption makes the marginal utility of giving them more and more greater than the marginal utility of helping anyone else, including those who are significantly worse off materially. And welfare egalitarians similarly have to contend with hungry elites, upon whom some combination of nature and nurture has imposed the awful burden of being even marginally content only when gorged with caviar and quail eggs. ${ }^{30}$

As a conception of religious freedom, unimpaired flourishing presents a striking variant on this normative difficulty. Religious belief need not be founded in reason, guided by reason, or governed in any way by the reasonable. Accordingly, the demands that religions place on the faithful, and the demands that the faithful can in turn place on society in the name of unimpaired flourishing, are potentially extravagant.

Religious belief can direct parents to withhold medical assistance from their children, or adults to withhold such assistance from one another or to refuse such assistance for themselves. It

${ }^{30}$ See generally Ronald Dworkin, What is Equality? Part 1: Equality of Welfare, 10 Phil \& Pub Aff 185 (1981) (critiquing theories of welfare equality), and especially id at 228-40 (discussing the problem of expensive tastes). 
can direct believers to maintain great caches of weapons against Armageddon; to give over their underage children for the sexual gratification of their religious leaders in the meantime; to spend all of their waking hours in arcane study, eschewing all other occupations; to follow dietary regimes that call for refined and expensive foods; or to ingest substances plausibly regarded by secular society as radically poisonous, dangerous, and habituating. Religion can demand sacrifices that range from vows of abject poverty, to the regular undertaking of expensive pilgrimages, to the ritual slaughter of species protected on grounds of civility or threatened extinction. It can underwrite employment practices that secular judgment would regard as grossly exploitative and dictate the subordination of women, persons in particular racial or ethnic groups, or homosexuals. To be at peace with their religious consciences, the faithful may require that public streets be closed to vehicular traffic on the Sabbath; that particular sites be preserved and freely accessible for their holy worship; and even that the basic institutions of their society be pervasively arranged in conformity with their religious precepts.

The potential of religious beliefs to be arbitrarily demanding, to be greedy in their demands on both the individual and the society committed to the unimpaired flourishing of its religiously faithful, is compounded by the possible all-or-nothing quality of religious dictates. In other domains, well-being is generally incremental-having the requirements of well-being partially satisfied is a benefit. But religious demands can be absolute or categorical. They can assume the form: "A, B, and $\mathrm{C}$ must all be fully in place or you are condemned to eternal damnation."

The principle of unimpaired flourishing, as a result, commends a vision of a world that is unrecognizable, unattractive, and ultimately incoherent. In this world, the faithful would be licensed to do as their faith requires, with little regard for the consequences as seen from the vantage of secular society. In this world, wealth would be distributed so as to support comfortably those whose religious commitments diverted them from remunerative pursuits, or otherwise required great investments of time and money. In this world, the faithful whose beliefs so required would receive disproportionate authority over decisions about the use of collective authority. The chaotic picture that emerges is ultimately incoherent in this sense: the demands of one faith would ultimately extend so far as to come into sharp conflict with the requirements of other religions, and some mechanism, presumably secular, would have to arbitrate. 
But, of course, no proponent of the constitutional privileging of religion actually means to take us into this ungainly world. Significantly, almost all judges and commentators who urge something like the principle of unimpaired flourishing nevertheless want collective authority in the United States to remain pretty much as it is; they merely want to find a haven for religiously motivated conduct at the margins of state authority. This produces incoherence of a much more immediate and troubling sort: proponents of unimpaired flourishing are in the unhappy position of offering an unexplainably selective, comparatively modest, practical agenda for reform, on the basis of a sweeping and deeply radical principle of political justice. The result is an analytical scramble. Various limitations are offered, often in combination. ${ }^{31}$ Religiously motivated acts that harm others, it is sometimes suggested, may be curtailed by state law, but the state may not interfere with religious believers on paternalistic grounds. As to the support of religious believers who cannot earn or must spend as a consequence of their beliefs, a baseline grounded, in effect, on the existing distribution of wealth and opportunity is urged, and claims to improve on the status quo for needy religious believers are disavowed. Or, it is suggested, secular needs must be balanced against religious needs.

These attempts to rescue unimpaired flourishing from its own logic are unsatisfying. If religious motivation signifies legal immunity only at the margins of state authority, there is good reason to suppose that in these cases we are actually responding

${ }^{31}$ Not surprisingly, proponents of privilege have trouble coming up with any satisfactory formulation for their position. See, for example, Michael W. McConnell, Religious Freedom at a Crossroads, $59 \mathrm{U}$ Chi L Rev 115, 168 (1992) ("[T]he Religion Clauses ... guarantee a pluralistic republic in which citizens are free to exercise their religious difference without hindrance from the state (unless necessary to important purposes of civil government).") (emphasis added); id at 169 ("The underlying principle is that governmental action should have the minimum possible effect on religion, consistent with achievement of the government's legitimate purposes.") (emphasis added); id at 170 (endorsing the "compelling interest test"). In our view, this riot of standards is not mere rhetorical slippage but an inevitable byproduct of any theory that accords religion a privileged constitutional status. Because there is no coherent normative justification for privileging religion, there is, of necessity, no principle to govern the balancing called for by the "compelling state interest"-or any other-formula. Of course, McConnell is right when he says, in the midst of announcing these competing standards, that " [n]o doctrinal formulation can eliminate the difficult questions of judgment in determining when the government's purpose is sufficiently important, when its chosen means are sufficiently tailored, or when the effect of the action on religious practice is sufficiently minor or indirect." Id at 169. But the fact that we must make hard judgments about what is "sufficient" does not eliminate the need for a defensible standard against which to judge sufficiency. 
to well-founded-if inarticulate-doubts about state authority in general rather than to the needs of religion in particular. On this account, if we valued liberty in general to the appropriate degree, there would be no need for the additional feature of religious motivation to enter the story. This may well be the best way to understand Yoder. Parents who have a systematic, reflective, and durable scheme for educating their children may be entitled to substitute their curricular judgment for the state's-at least at the margin. If so, then Yoder may have been correctly decided; if not, then the religious basis of the Amish approach to education ought not matter.

Indeed, important constitutional benefits depend upon our willingness to recognize this connection between specifically religious interests and more general principles of privilege. Religious groups perform a valuable service in a freedom-loving society: they push at the margins of liberty. But that service is best realized when the regime of law refuses to privilege religion, so that the systematic but idiosyncratic impulses of organized religion act on behalf of us all when they help to maintain or expand the ambit of constitutionally secure choice.

Tests that purport to balance secular and religious needs against each other are at best fronts for more substantive but obscure intuitions about how particular claims for religious exemptions ought to come out. What exactly can such tests for religious exemption mean? Are they meant to be restatements of an overall utilitarian calculus of the form: do we improve utility overall if we pursue Legal Rule A over Legal Rule B, or vice versa? If not, what possible meaning can they have? One is left with nothing but a fictive interest group deal in which religions get "something" but not "too much." And if, on the other hand, utilitarian calculus is indeed the core of the proposed balance, this approach seems at once to have read the principle of unimpaired flourishing entirely out of the equation and to have reduced the issue of exemptions to one of social policy that legislatures are best able to determine.

Beset by these difficulties, judges and commentators who favor some form of constitutional privilege for religion have taken refuge in the compelling state interest test. The compelling state interest test is normally applied in constitutional contexts where practically all instances of collective behavior with the triggering feature are expected to be unconstitutional, but extraordinary cases can be imagined that would have the triggering feature but not fail constitutional scrutiny. Though seldom applied literally, 
and hence an imperfect guide to what actually distinguishes the extraordinary case, the compelling state interest test, with its strong presumption against validity, seems a reasonably useful banner under which to conduct analyses in cases of this sort. Explicit racial distinctions that disfavor racial minorities provide the classic example.

But in many religious exemption cases, the presumptive invalidity implicit in the compelling state interest test is misplaced. There is a substantial range of religiously motivated conduct-readily observable in contemporary national experience -that quite clearly must yield to conflicting secular laws. This has tacitly been recognized by the all-but-total failure of Sherbert's dictum to travel outside the unemployment benefits situation. As we have noted, the Supreme Court has paid lip service to that standard in some non-Sherbert exemption cases, but found the test satisfied in all except Yoder. That experience could merely reflect the distortions of a small sample, of course, were it not for the fact that the courts of appeals have similarly applied the test in words only, and so found a diverse set of garden-variety legislative interests powerful enough to overwhelm the claims of religious exemption. ${ }^{32}$ Under these circumstances, the compelling state interest test becomes just another balancing test, obscuring rather than clarifying analysis. Its invocation here threatens to dilute the meaning of the test in its other, more proper, applications.

To this point, we have focused on the unattractive consequences that would follow were we to take the principle of unimpaired flourishing to heart. The difficulty with that principle only deepens when we consider what drives the impulse to treat religious practice in this special and favored way in the first place.

\section{The Normative Difficulties of Unimpaired Flourishing}

\section{The sectarian defect.}

In a liberal democracy, the claim that one particular set of practices or one particular set of commitments ought to be privileged (as we have used that term) bears a substantial burden of justification. As we shall see, the background circum-

${ }^{32}$ See generally Note, 78 Va L Rev 1407 (cited in note 16) (describing the poor track record of Free Exercise claims in the federal courts of appeals). See also EEOC $v$ Townley Engineering \& Mfg. Co., 859 F2d 610, 625-29 (9th Cir 1988) (surveying Free Exercise decisions by the federal courts). 
stances-that religion is singled out for distinct and emphatic treatment in the text of the Constitution, that many of the colonists fled religious persecution under circumstances that would have made religious liberty vital, that there are various features of religious liberty in our working constitutional tradition that seem at once important and well settled-do not in themselves support the proposition that religion ought to be privileged. An attractive and full account of religion's place in our constitutional tradition can proceed from protection rather than privilege. Justification for the privileging of religion must proceed on normative grounds.

Religious believers have available to them one particular justification along these lines: "Our God's commands," they might say, "are the highest commands; we must answer to them in priority to the mundane commands of the State." This is straightforward enough, and might be a good reason for privileging religion in a monistic society of shared religious belief. Note, though, that the constitution would privilege only "our" religion, not religion generally. Our God speaks to (the hypothetical) us with binding normative authority, and nothing more need be said. Our God's authority does not give us a reason for privileging anyone else's religious commitments. Indeed, the sorry world history of religious conflict suggests that one religion's belief system might give it a singularly ferocious reason to impeach the authority of another religion's belief system. Certainly there is nothing in this line of speculation that resonates with the themes of diversity and tolerance that are integral to our constitutional tradition generally and our tradition of religious liberty in particular.

We can remake the religious believer's claim, to turn outward in a reciprocal spirit more suitable to liberal constitutionalism in a plural society: "God's commands are the highest commands. We should recognize that there are other religious groups who believe that their 'God' is the true God, and who take themselves to be bound to the word of their 'God' as we are in fact bound to God's." as among divergent religious beliefs, but nonetheless remarkably

33 Michael McConnell takes a position of this kind when he recommends as a constitutional principle the proposition that "[e]ven the mighty democratic will of the people is, in principle, subordinate to the commands of God, as heard and understood in the individual conscience." Michael W. McConnell, The Origins and Historical Understanding of Free Exercise of Religion, 103 Harv L Rev 1409, 1516 (1990). 
monistic in the view that there was $a$ god-or the normative equivalent, from whom or which binding precepts emanated-this would be a basis for the constitutional privileging of religion, perhaps. But we are not such a society; there are many persons in our society who are not religious at all, and many others who are not religious in the pertinent sense--that is, who do not understand their lives to be ordered such that their highest commitments are to a set of religious commandments.

In a nation with many groups, many values, and many views of the commitments by which a good life is shaped, the shared understanding among some groups that they are each bound by the commandments of a (different) god they believe deserves/demands obeisance is unacceptably sectarian as a basis for the constitutional privileging of religion. Their claim, as a union of groups within a broader, pluralistic society is no different in principle than the sectarian claim of the religious believer we first considered, who reasoned, wholly from within his own religious tradition, that his God was the true, supreme god, and thus the state must permit each believer in the true God to subordinate the state's commands to those of God. As against the artist for whom art is the highest command of life, the activist to whom the pursuit of racial justice is all, or any of us who happen not to be members of the union of the deeply religious, the members of the union have no reason to offer, from within their own beliefs, for the privileging of their commitments that the rest of us lack with regard to our deep commitments.

\section{Two nonsectarian strategies.}

There are, however, two arguments for the constitutional privileging of religion that do not suffer from this sectarian defect. The first appeals to persons within our political community to recognize-from the outside, in effect-the anguished state of the religious believer who is under state fiat to behave in a way that flatly contradicts the demands of her religion. The second suggests that organized religion enables our society to maintain an important place for the moral, non-self-regarding aspects of life.

One version of the first argument asks us to consider the potential stakes for the religious believer of disobeying her God's commandments. They may be such that it is an understatement to speak of them as matters of life and death; they may be no less than eternal paradise or damnation. We cannot be expected to act as though those are the stakes, of course, but we can ap- 
preciate the unhappy state of someone who regards them as the stakes. This seems an unpromising way to put the case. It asks us to assume-in a way that seems especially inappropriate when it comes to matters spiritual-that self-interest rather than conscience is the stronger human drive. It expects us to treat the religious believer's very long-term (possibly abstract, metaphorical) self-interested reasons for obedience as motivationally more powerful than other persons' immediate self-interest and driving passions-the deeply devoted artist, the parent with a hungry child, or the lover overwrought with love, who are driven to disobey the law. Furthermore, it asks us either to treat all religions as having the structure of eternal reward/punishment because some do, or to parse among religions on this peculiar ground. Interestingly (and this may not be a criticism), it also asks us to accept as true for the believer that heaven and hell are at stake, while holding to the contrary as a matter of our own belief. Unless we tacitly deny the truth of the believer's perspective in this ironic way, the believer's situation may not seem so dire: she has only to suffer mortal punishment in exchange for eternal paradise.

The better version of this first argument for privileging religion emphasizes mortal conscience rather than eternal consequences. It encourages us to see that the religious believer is in the grip of conscience-a motivation that is at once powerful and laudable-and to regard that circumstance as grounds for excusing her from obedience to laws that force her to choose between her conscience and her well-being at the hands of the state. But while conscience is the better motivational grounds for privileging religion, there remain persuasive objections to the claim. Again, religious conscience is just one of many very strong motivations in human life, and there is no particular reason to suppose that it is likely to matter more in the run of religious lives generally than will other very powerful forces in the lives of both the nonreligious and the religious.

This is not to trivialize religious interests. We have no trouble agreeing with Douglas Laycock when he argues that it would be an error to maintain that "[a] soldier who believes he must cover his head before an omnipresent God is constitutionally indistinguishable from a soldier who wants to wear a Budweiser gimme cap." ${ }^{34}$ Likewise, we agree with Michael McConnell that a Saturday work schedule imposes qualitatively different burdens

34 Laycock, $1990 \mathrm{~S}$ Ct Rev at 11 (cited in note 16). 
on those who "like to go sailing on Saturdays" and those who "observe the Sabbath" on that day. ${ }^{35}$ But these comparisons largely beg the question. Of course, burdens upon religious practice differ from burdens upon tastes in fashion and recreation. Do they also differ from the considerably more weighty burdens imposed by secular commitments to one's family, or by secular moral obligations, or by physical disabilities? ${ }^{36}$

Consider two cases:

(1) Goldman is an army officer. His faith requires him to wear a yarmulke. The yarmulke is inconsistent with the Army uniform. The Army insists that Goldman must resign his commission or comply with the uniform regulation. The Army relies entirely on its interest in uniform appearance; it does not contend that Goldman's obligation to wear the yarmulke will in any other way impair his performance.

(2) Collar is an army officer. He has a rare skin disorder on his neck that prevents him from wearing a tie. Army uniform regulations require that all officers wear ties on certain occasions. The Army insists that Collar must resign his commission or comply with the regulation. The Army relies

${ }_{35}$ McConnell, $59 \mathrm{U}$ Chi L Rev at 125 (cited in note 31).

36 McConnell has recognized the relevance of such analogies. To distinguish laws that disproportionately disadvantage members of a specific race from laws that disproportionately disadvantage members of a specific religion, McConnell has argued:

Religion is more like handicap than it is like race .... If the paradigmatic instance of race discrimination is treating people who are fundamentally the same as if they were different, the paradigmatic instance of free exercise violations or handicap discrimination is treating people who are fundamentally different as if they were the same.

Michael McConnell, 57 U Chi L Rev at 1140 (cited in note 16). Yet, although McConnell invoked the analogy between religion and handicap to justify treating religious believers differently, he did not consider the negative implications of the analogy: if the Constitution permits government discretion to decide when to accommodate handicaps, does it also permit equal discretion with respect to religious accommodation?

Some writers have suggested that religious belief imposes unique burdens because religious believers are, or ought to be, disabled from advancing their religious interests through ordinary political processes. See, for example, Greene, 102 Yale L J 1611 (cited in note 16) (making an argument of this variety). But clearly, religious believers to date have not been barred from active participation in popular politics-see, for example, text accompanying notes 116-35 (discussing the Religious Freedom Restoration Act of 1993 and other legislative efforts at accomodation)-and, while the question is beyond the scope of this essay, we are not attracted to the claim that they should be so barred. For further relevant argument by one of us, see Christopher L. Eisgruber, Madison's Wager: Religious Liberty in the Constitutional Order, $89 \mathrm{Nw}$ U L Rev (forthcoming Winter 1995) (criticizing doctrinal restrictions on religious argument in public debate). 
entirely on its interest in uniform appearance; it does not contend that Collar's disability will in any other way impair his performance.

Should we regard Goldman's interests as more weighty than Collar's? Does the Army have a constitutional obligation to accommodate Goldman's religious burden if it accommodates Collar's disability, or vice-versa? To maintain that the Constitution privileges religion, we would have to uncover some ground for constitutionally favoring Goldman's interests over Collar's, a ground that is not impermissibly sectarian or partisan; and that is precisely what is lacking in the case for privileging religion.

The second nonsectarian argument for the constitutional privileging of religion appeals to our desire as a society to remain alive to the moral, non-self-regarding aspects of life, and sees organized religion as a taproot of this vital aspect of human flourishing. But while religion sponsors the highest forms of community, compassion, love, and sacrifice, one need only look around the world, or probe our own history, to recognize that it also sponsors discord, hate, intolerance, and violence. Religion is enormously varied in the demands it places on the faithful. As we observed earlier, religious faith or belief need not be founded in reason, guided by reason, or governed in any way by the reasonable. Religious commandments can be understood as inspired by beneficent forces that are beyond human comprehension or verification, or by the result of the spite, play, accident, or caprice of entities or forces that do not necessarily hold human welfare paramount. The only limitations are those of the human imagination or the range of divine circumstance (depending on whether one looks from within or without religious beliefs): the bounds of the former are very broad indeed, and the logic of the latter implies the absence of any bounds whatsoever. We mention all this because, while the commitment to forces outside and above ourselves seems an attractive human capacity and impulse, the substance of the commitment matters, and there is no warranty on the laudability of religious commitments.

We must remember that the claim for the laudability of religious commitment is offered as a reason for exempting behavior that defies otherwise valid general laws. This simple fact is prejudicial to abstract arguments for the virtues of religious conscience. If we believe in a given case that the polity's decision to enact a law was sound, the claim that a conscientious defiance of this same law is virtuous requires some moral gymnastics. There are situations in which our own ambivalence or distaste toward 
the necessary makes it possible to hold these two views simultaneously. The draft is a good example. We go to war with great moral unease. At best, the intentional killing of soldiers and civilians seems justified rather than just. In such a case, we can sensibly believe that the conscientious dissenter is a morally attractive figure, epiphying the moral regret that we ourselves feel and hope not to lose, even as we conscript thousands and calculate how to destroy our enemy. But this is a special case, and we would be mistaken to extrapolate from it to a general view about religious conscience.

Religions, of course, are by no means the only sources of moral reflection and impulse; nor are moral reflection and impulse the only forms of elevated human activity. These are not small quibbles to be worked out empirically. They go very much to the heart of the objection to privileging religion. A plural democratic society like ours must develop constitutional principles that recognize that a citizen's ability to contribute to the regime does not depend upon membership in any particular religion, or, indeed, upon religiosity at all. To hold otherwise would simply be another way to insist upon the truth of a particular religion, or to deny the truth of secular ethics. Of course, it might be true, as a contingent empirical matter, that religious faith correlates well with civic virtue, even if there is no theoretically necessary relationship between the two. But that sort of contingent empirical connection between religious belief and constitutional objectives is not an appropriate ground for privileging religion.

Once we have agreed that society must respect the virtue of individuals without regard to their religious beliefs, the claim that religion so breeds virtue that it is constitutionally privileged becomes indefensibly partisan among conflicting views of what is valuable in life and how that which is valuable is best realized. We use the term partisan here, rather than sectarian as before, because there is a difference between the argument that God's commands are prior to those of the state and the arguments we are considering now. The nonsectarian arguments are available to a person from outside religious belief, unlike the sectarian claim for obeisance. But they are nevertheless inconsistent with our constitutional tradition, which contemplates a modern, pluralistic society, whose members find their identities, shape their values, and live the most valuable moments of their lives in a grand diversity of relationships, affiliations, activities, and passions that share a constitutional presumption of legitimacy. 
To observe that the burden or nobility of religious belief offers no grounds for constitutionally privileging religion is not to deny the capacity of legislative bodies to accommodate religious beliefs or even help religious institutions to prosper, where good reasons exist for so doing. Some scholars mistakenly find traces of constitutional privilege implicit in the very idea of religious accommodation. McConnell, for example, writes: "There is no way to distinguish between government action that treats a religious belief as worthy of protection, and government action that treats a religious belief as intrinsically valuable. Why accommodate religion unless religion is special and important?"37 But, as our analysis suggests and as McConnell himself elsewhere recogniz$\mathrm{es}^{38}$ religious obligations in some respects resemble physical disabilities. ${ }^{39}$ Both religious obligation and physical disability may make it hard for individuals to comply with otherwise neutral laws. We may make exceptions to accommodate the welfare of the religious or the disabled, even if we wish such exceptions were unnecessary. Nonsectarian judgment comfortably supports the conclusion that for some people under some circumstances the demands of religious belief are "special and important" in the same sense that disabilities are "special and important": both can have profound effects upon individual well-being. But it does not follow that either religious beliefs or disabilities are "intrinsically valuable." Likewise, policy makers might legitimately take into account the instrumental value of religious institutions as aids to moral development in a democratic society. But, at most, this argument simply indicates that we should think carefully before reading the Establishment Clause to fetter legislative discretion to advance religion where it is judged to have nonsectarian social utility.

37 McConnell, 59 U Chi L Rev at 151 (cited in note 31).

${ }^{38}$ See McConnell, $57 \mathrm{U}$ Chi L Rev at 1140 (cited in note 16).

39 John Garvey has taken this idea still further by offering the provocative suggestion that the law's treatment of insanity may in some respects be the best model by which to understand the constitutional treatment of religious belief. Garvey, 18 Conn L Rev at 798801 (cited in note 16). The analogy is easy to overstate: obviously, we do not, and ought not, consider religious belief a matter of regret in the way that we quite rightly consider insanity a matter of regret. Nevertheless, in some settings, Garvey's startling comparison does help us to understand the exemption problem. 
3. Generalized versions of the claim for privileging: If you can't beat'em ....

Thus far, our objections to privileging religion have shared a common theme: they have emphasized the sectarian or partisan character of the arguments on behalf of religion. This raises the possibility that a constitutional privilege for religion could be rehabilitated if it were generalized to include a wider range of human commitments and thus avoid the complaints of sectarianism or partisanship. The idea would be to privilege all acts of conscience, not merely those that are rooted in a conventionally religious system of belief.

The difficulty with this approach becomes clear when we try to give content to the idea of conscientious commitment. Need a conscientious commitment be framed in recognizably moral terms? Does it require a system of belief, or can it be simply a sharp impulse? Need it involve an element of sacrifice? On the one hand, if we try to contain the idea of conscience within relatively narrow bounds, we will encounter our old difficulties of explaining why a particular form of commitment should be treated differently from comparably gripping life projects. On the other hand, if we broaden conscience to include a great swath of the deep commitments people hold, we face the fantastic idea that it is a matter of constitutional regret whenever an otherwise valid law collides with the commitments of an individual or group.

Our best account of a general privileging of conscience would understand the key term, conscience, as follows: An important mark of a well-formed person is an internal gyroscope that pulls her toward doing the right thing and away from doing the wrong thing. As right and wrong are understood here, self-interest-in an immediate, material, short-term sense-is only coincidentally congruent with rectitude. The tug of this gyroscope toward the right thing is consciously experienced, but in many forms: as raw impulse, as deep but unlocated conviction, or as fully articulate and located within a scheme of belief. The provenance or bona fides of this tug is similarly and associatedly diverse: if it is consciously acknowledged at all, it may range from the command of a deity, to the interpreted understanding of a covenant, to a mystic and intuitively driven sense, to a constructed and coherent, but free-standing system of moral judgment. Under some circumstances-chronic and life shaping, or acute and focused-this pull toward rectitude becomes a central, dominating feature of a person's motivation and self-identity. When these circumstances obtain, and a person acts on them, she is perform- 
ing an act of conscience. Acts of conscience, on this account, are what should be constitutionally privileged.

We have tried in this account to offer a generous conceptual platform on which to found the privileging of conscience, but the problems of justifying such a privilege remain. As with religion more narrowly, we have to separate the general appeal of people being motivated by conscience from the content of their conscientious motivations. It is surely a good thing that people have such motivations, and we can imagine totalitarian legal regimes that would deform and destroy this capacity. But a constitutional privileging of conscience is not what divides us from such a regime.

As to the substance of acts of conscience, it by no means follows from the internal phenomenology of conscience, which has rectitude at its core, that we should be optimistic that conscientious impulses will lead persons to do good things. Both good and evil can emanate from conscience: the feeding of the poor, perhaps, but also the purification of the caucasian race. Again, it must be remembered that conscience is being offered here to license the defiance of otherwise valid laws. Perhaps the claim is essentially one of deep sympathy for the person caught between the demands of her conscience and the demands of her state. But we must still justify constitutionalizing sympathy for the strong pull of conscience over the pulls of love, passionately demanding life projects, and the infinitely creative demands of strong psychological compulsion.

Of course, as we note below, settled and attractive constitutional doctrine does in fact privilege a broad variety of conduct that is relevant to conscientious commitments. Issues of conscience play an important role in decisions about family, friendship, belief, and expression, and these decisions receive constitutional privileging through doctrines like privacy, autonomy, and speech. Could not we describe this congeries of constitutional values, all of which bear some connection to moral identity, as the province of conscience? And would not it then be obvious-albeit tautological-that the Constitution privileges conscience? Indeed, we might proceed even more boldly and say that these constitutionally privileged aspects of human conduct are all "religious" because they involve persons in the kinds of questions that are an important focus of religious concern. Having so generously redefined religion, we could conclude that it is indeed privileged by the Constitution. 
Well ... fair enough. No doubt the truth of any proposition depends upon how one defines the terms composing it, and there is not much point to insisting upon strict standards of right and wrong in a matter so thoroughly conventional as the definition of words. Nevertheless, there are good reasons to decline this definitional gambit. Most important, it utterly fails to advance our discussion. The religious-exemption issue we have been considering begins at precisely the point where the general shield of private behavior leaves off. If we elide religion with these other matters already more or less uncontroversially shielded by the Constitution, then we need new language to address the question of what we have heretofore been calling religious exemptions. We gain nothing here, and may in fact cause conceptual mischief elsewhere: using religion or even conscience to redescribe values like privacy or autonomy may badly unsettle our understandings of the Establishment Clause.

\section{The Failed Argument from Text and History}

Often, proponents of a privileging view claim that a simple textual or historical argument distinguishes burdens upon religion from even serious impositions upon secular well-being. This argument sets normative concerns aside and claims a legislated privilege, even in the face of normative difficulties. The Constitution is thus read like a tax code or a treaty, the meaning of which is historically located, recoverable, and articulate to the question of privilege. But neither the text nor the history of the founding (even were we to concede that the founding is the only or most relevant historical period) enables us to choose between privileging and protecting accounts of religious liberty. We believe this state of affairs reflects more general truths. The text of the Constitution is seldom if ever dispositive of interesting constitutional questions. Neither is the history. It is conceptually impossible that the complex social and legal events surrounding the founding could answer hard questions without a normative view to guide the interpretive enterprise. As we and others have argued elsewhere ${ }^{40}$ the project of constitutional interpretation involves the pragmatic pursuit of political justice, not the positivist recovery of fixed historical meaning.

40 Ronald Dworkin, A Matter of Principle 34-57 (Harvard, 1985); Lawrence G. Sager, The Incorrigible Constitution, 65 NYU L Rev 893, 953-59 (1990); Christopher L. Eisgruber, Justice and the Text: Rethinking the Constitutional Relation Between Principle and Prudence, 43 Duke L J 1, 3-18 (1993). 
The constitutional treatment of religious liberty is no exception to that lesson. Efforts to privilege religion on the basis of purely textual or historical arguments fail to withstand scrutiny. Consider, for example, the line of argument taken by Douglas Laycock:

Religion is unlike other human activities, or at least the founders thought so. The proper relation between religion and government was a subject of great debate in the founding generation, and the Constitution includes two clauses that apply to religion and do not apply to anything else. This debate and these clauses presuppose that religion is in some way a special human activity, requiring special rules applicable only to it. ${ }^{41}$

Understood as a stark argument from text on behalf of the privileging of religion, this is singularly unconvincing. Religion is indeed "special" in the following two ways: (1) religious activities are more important than matters of fashion or recreation, such as wearing a "gimme cap" or sailing; and (2) people are especially likely to undervalue, or persecute, religious activities different from their own. These differences justify constitutional protection of religion against discrimination..$^{42}$ But they provide no ground for privileging religion by comparison to comparably serious secular commitments. Considered as freestanding fragments of constitutional text, the Religion Clauses are at least as congenial to protection as they are to privilege. Given two available readings of these clauses, it seems perverse to prefer the privileging view, which, as we have seen, is normatively unattractive and inconsistent with the thrust of our constitutional commitments.

Even if we imagined, for the sake of argument, that the Religion Clauses of the First Amendment should be read to privilege religion, we still would have to account for the subsequent impact of the Equal Protection Clause, which might have equalized (among other things) religion and nonreligion, and thereby

11 Laycock, $1990 \mathrm{~S} \mathrm{Ct} \mathrm{Rev} \mathrm{at} 16$ (cited in note 16). Laycock continues, "To distinguish between a yarmulke and a gimme cap is not to discriminate between indistinguishable head coverings, but to distinguish a constitutionally protected activity-religious exercise-from an activity not mentioned in the Constitution." Id. As indicated above, distinguishing between a yarmulke and a gimme cap is a matter of simple common sense. Laycock's textual argument seems, however, to reach harder cases as well, since, for example, neither physical disabilities nor the family receive explicit mention in the Constitution.

${ }^{42}$ William Marshall makes the same point. Marshall, $58 \mathrm{U}$ Chi L Rev at 325 (cited in note 16). 
deprived religion of any special constitutional respect it had enjoyed before Reconstruction. ${ }^{43}$ From a purely textual standpoint (which we do not commend), this argument seems especially important with respect to cases involving state law, since the Free Exercise Clause does not mention the states, and the Fourteenth Amendment does not mention religion.

Laycock's references to the founding generation shade from text into history, and some commentators have made similar arguments in more unambiguously historical terms. Probably the most richly documented attempt to derive the principle of unimpaired flourishing from history is Michael McConnell's; his failure illustrates why history cannot dispose of the questions that concern us.

McConnell's extensive research into the origins of the Free Exercise Clause contrasts Thomas Jefferson's views with James Madison's. According to McConnell, Jefferson took an "'Enlightenment-Deist-rationalist' stance toward religious freedom," and "never once showed concern for those who wish to practice an active faith." ${ }^{45}$ For Jefferson, "liberty of conscience meant largely freedom from sectarian religion, rather than freedom to practice religion in whatever form one chooses." ${ }^{46}$

McConnell argues that Madison was more sympathetic to the demands of religious practice. Madison never displayed Jefferson's "disdain ... for the more intense manifestations of religious spirit." ${ }^{\text {"77 }}$ According to McConnell, Madison's "more affirmative stance toward religion" led him to "advocate [ ] a jurisdictional division between religion and government based on the demands of religion rather than solely on the interests of society." 48

McConnell believes that "[n]o other figure played so large a role in the enactment of the Religion Clauses as Jefferson and Madison." ${ }^{39}$ We might reasonably conclude that the serious divergence between the views of these two pivotal thinkers renders history an unreliable guide to interpretation of the Religion

43 William Marshall has also drawn attention to the possibility that the Equal Protection Clause has superseded or altered the Religion Clauses. Marshall, 40 Case W Res L Rev at 374 (cited in note 22 ).

44 McConnell, 103 Harv L Rev at 1452 (cited in note 33).

45 Id at 1453.

46 Id.

47 Id at 1452 .

48 Id at 1453.

49 Id at 1455. 
Clauses. We might also suspect that, as has already been suggested, the Equal Protection Clause may be as important as the Religion Clauses. The intentions of Jefferson and Madison have no bearing on that clause's meaning.

McConnell, however, presents a historical argument purporting to show that "Madison, with his more generous vision of religious liberty, more faithfully reflected the popular understanding of the free exercise provision that was to emerge both in state constitutions and the Bill of Rights." ${ }^{\text {50 }}$ Even if we suspend doubts about this claim, and even if we ignore complications introduced by the Fourteenth Amendment, McConnell's history does not resolve the questions we posed earlier when comparing the cases of Goldman (the military uniform yarmulke claimant) and Collar (the military uniform medical claimant). There is more than one way to reject Jefferson's disdain for religion. At a minimum, the Madisonian position (as McConnell describes it) prohibits us from disparaging Goldman's beliefs. If confronted with a soldier who simply dislikes the idea of wearing a uniform, we might say that her problem is her own fault. If confronted with a soldier who (to borrow Laycock's hypothetical) is inordinately fond of a Budweiser promotional hat, we might say that his preferences are trivial. We cannot say either of those things about Goldman. But this "more affirmative stance," which recognizes the "demands of religion," need not lead us to prefer Goldman's claims to Collar's. For just as we must recognize that Goldman's claims are neither blameworthy nor trivial, the same is true of Collar's. Even if we set Madison up as the unique arbiter of the meaning of the Religion Clauses, ignore the Fourteenth Amendment, and blind ourselves to the normative difficulties of privileging religion, McConnell's history can not bring us to unimpaired flourishing.

E. Misreadings of the Status of Religion in Our Constitutional Tradition

1. Uncontroverted elements of (religious) liberty.

Much of the appeal of unimpaired flourishing or other privileging views of religious freedom comes from the observation that our constitutional tradition does seem to exempt religious belief and certain aspects of religious practice from the reach of state 
authority. This much seems common ground: Persons are entitled to their religious beliefs and cannot on account of those beliefs be punished or deprived of benefits otherwise their due; further, important aspects of religious practice-for example, the choice by a religious group of their compensated spiritual leaders-are largely beyond the reach of the collective authority of the state. What may seem to follow is that religion is systematically valued both in our constitutional tradition and in our best understanding of political justice in a way that should carry over to the question of exemption from otherwise valid general laws. On this account, it seems arbitrary and wrong to deny religion in the exemption context the special status it is acknowledged to enjoy elsewhere.

But this is a misreading of the common ground where religious belief and certain elements of religious practice are beyond the reach of collective authority. The best explanation for each of these attractive limits on state authority does not involve privileging religion. We can see this if we consider each in turn a little more closely.

Consider first the observation that persons are, in a deep sense, entitled to hold their particular religious beliefs. No one may be punished for her religious beliefs; or made to affirm other beliefs; or denied the opportunity to discuss and publish her beliefs; or prevented from associating with others to reflect upon, celebrate, and consummate their beliefs in (otherwise benign) ceremonies of affirmation or worship. All this is true, and sits high in the pantheon of constitutional truths; but none of it is distinct to religious belief. We have in our constitutional tradition a strong freedom of belief, famously invoked by Justice Jackson in West Virginia State Board of Education v Barnette:

If there is any fixed star in our constitutional constellation, it is that no official, high or petty, can prescribe what shall be orthodox in politics, nationalism, religion, or other matters of opinion or force citizens to confess by word or act their faith therein. ${ }^{51}$

Our freedom of belief extends to political, aesthetic, and moral matters, to matters that are areligious and antireligious. It is certainly true, for example, that belief in an orthodox deity cannot be made a condition of public office; but neither can belief in the virtues of religion generally, or belief in the falsity of reli- 
gion, or belief in the virtues of maintaining an open mind to religion, or belief that religion is worth worrying about, or belief in the justness of capital punishment or the redistribution of wealth, or belief in the comparative genius of Van Gogh and Giorgione, or belief in the likelihood that the Higgs particle actually exists and will help us unravel the secrets of the universe. It bears emphasis, if we have somehow failed to make the point, that these beliefs are privileged not on analogy to religious beliefs, or on the view that they occupy the same role in the lives of the persons who hold them as do religious beliefs, but on the simple and sufficient ground that they are beliefs, and that our political community deeply respects the capacity of its members to arrive at and champion their individual understandings of the world.

Consider next the observation that important religious practices have a distinct status in our understanding of constitutional justice, as illustrated, for example, by the widely held view that it would be constitutionally inappropriate to apply Title VII prohibitions of race and sex discrimination to the employment of religious leaders such as priests, pastors, or rabbis. ${ }^{52}$ Here, the story is a little more complex, but ends in much the same way as did our observations about freedom of belief. We have in our constitutional tradition-in clear spirit, and if not in clear letter, only because the occasions to spell the point out have not often arisen-an important, morally indispensable sense of the private and the public. Thus, the state can tell us whom we must accommodate at our lunch counters, but not at our dinner tables. The question is not one of "state action," but of state authority, and it does not turn on an obtuse, clunky view that private and public

s2 Title VII, of course, exempts religious organizations from the statutory provisions prohibiting discrimination in employment on the basis of religion. See 42 USC $\$ 2000 \mathrm{e}-1$ (1988). See also Corporation of Presiding Bishop v Amos, 483 US 327 (1987) (upholding the constitutionality of this exemption). Surprisingly, Title VII contains no express exemptions whatsoever for race discrimination or sex discrimination by churches. Douglas Laycock has accordingly concluded that, constitutional considerations aside, "the Act forbids the requirement that Catholic priests be male." Douglas Laycock, Towards a General Theory of the Religion Clauses: The Case of Church Labor Relations and the Right to Church Autonomy, 81 Colum L Rev 1373, 1375 (1981). Federal courts confronting this issue have implied an exception or ruled the statute unconstitutional. See, for example, McClure v Salvation Army, 460 F2d 553 (5th Cir 1972) (implied statutory exemption permits religious organizations to discriminate on the basis of sex in some circumstances). See also Laycock, 81 Colum L Rev at 1375-76 (summarizing cases). The Supreme Court has not spoken to the issue directly, but it has suggested that the First Amendment would protect church autonomy. See, for example, NLRB v Catholic Bishop of Chicago, 440 US $490,504,507$ (1979). 
can be mechanically or sweepingly distinguished. But the distinction exists, and it may ultimately be the most important source of liberty there is. The state cannot insist that we ignore the race or religion of potential marital partners, or prescribe how our spouses and we divide up our household responsibilities, but it can and must protect marital partners from the abuse of their spouses. The quality of public and private is nuanced to domain and demand.

Often, private behavior takes place in private places and in private ways: classically, in the home, with relationships born of love, respect, and duty, not contract and compensation. Public behavior finds its most common venues in more widely accessible spaces. One form of public behavior is largely economic; it centers around the office, factory, hotel, or restaurant, and its most common mode is the commercial transaction, the exchange of goods or services for money. Another form is political; it transpires most frequently in assembly halls, streets, and newspapers, and its common modes include the vote and the argument.

Often, but not always. Organized religious activity projects distinctly private behavior into public space and involves distinctly private relationships that are bound by contract and compensated by dollars. Religious leaders are moral advisors, confidants, friends, and spiritual guides. The state cannot prescribe a nondiscriminatory protocol for a group's choice of the person who is to bear this private responsibility to its members any more than the state could prescribe such a protocol for the selection of a psychiatrist, or of a neighbor in whom to confide one's hopes and concerns. The aspects of religious practice that are uncontroversially secure from the reach of some state commands are so secure because they are private in general and recognizable ways, not because they are religious.

There are, of course, aspects of all these relationships-priest/parishioner, psychiatrist/patient, friend/friend-that are appropriately vulnerable to state regulation. A religious group may be restrained from making a child its leader under circumstances threatening to the child's well-being, or enslaving or otherwise coercing the service of its adult religious guide, or beating or starving her in the name of ecstatic insight.

The controversial aspect of religious exemptions begins at precisely the point where the general shield of private behavior leaves off. In the present state of constitutional law, persons are not entitled to consume banned drugs like peyote alone in the privacy of their homes, or with good friends who join them in a 
search for enlightenment through altered states of consciousness; willing partners are not entitled to enter into polygamous or polyandrous marriages; parents are not allowed to determine that the best possible education for their teenage children is full integration in the adult life of their family and community (if the state insists on a higher minimum of formal education); and a man who quits his job because he wants to be with his ailing wife on Saturdays is not thereby constitutionally entitled to continued qualification for unemployment insurance. Hence, Smith, ${ }^{53}$ Reynolds, ${ }^{54}$ Yoder, ${ }^{55}$ and the Sherbert ${ }^{56}$ line are the cases that we must address. Analysis of them cannot borrow from situations where religious behavior derives constitutional solicitude from the general privilege available to private conduct, including private conduct that takes place in public settings.

\section{The Sherbert Quartet.}

Sherbert and the short but durable line of cases that follow its lead are widely perceived as supporting the privileging view of religious freedom. In each of these cases, the Court held that a religiously motivated person was constitutionally entitled to retain her eligibility for state unemployment insurance, notwithstanding her observation of the Sabbath ${ }^{57}$ or scrupled refusal to work in the manufacture of armaments. ${ }^{58}$ Sherbert was the first case to assert that laws interfering with religiously motivated conduct must be analyzed under the compelling 'state interest test. $^{59}$ While that promise is largely unfulfilled in other contexts, Sherbert itself has never been directly questioned by the Court and enjoys widespread support in critical commentary. On the privileging account, Sherbert is taken at its most literal and expansive word: most of us, most of the time, must take laws as we find them, but when we act in response to the dictates of our religion, the laws must yield to us unless they are crucial to very important state interests.

33494 US 872 (1990).

54 98 US 145 (1878).

55406 US 205 (1972).

${ }^{66} 374$ US 398 (1963),

${ }^{57}$ Id at 410; Hobbie $v$ Unemployment Appeals Commission of Florida, 480 US 136, 140-41 (1987).

${ }^{58}$ Thomas $v$ Review Board of the Indiana Employment Security Division, 450 US 707, 709 (1981).

59 374 at $406-07$. 
In Smith, justices on both sides of the exemption issue seemed to agree-at least tacitly-that Sherbert must be understood as privileging religion in this way. The four justices who resisted the majority approach to religious exemptions rested their case squarely on Sherbert; ${ }^{60}$ and Justice Scalia, writing for the majority, struggled unconvincingly to confine a privileging view of Sherbert to the unique circumstances of the unemployment insurance cases. ${ }^{61}$ Commentators on the exemption problem largely replicate the binary structure of disagreement among the justices in Smith: either Sherbert is right and religiously motivated conduct prevails against all but the most compelling of state interests, or Sherbert is wrong, and religiously motivated conduct is not so privileged, bringing serious constitutional scrutiny to an effective close.

Neglected on all sides is an understanding of Sherbert that depends on the protection of minority religious believers rather than the privileging of religiously motivated conduct. Government need not sympathize with religious interests to accommodate them. That much is clear from our attitude toward physical disabilities: we certainly do not consider disabilities beneficial to society, but we believe it wrong to hold the disabled responsible for their condition and believe that the government should do something to make their lives easier. Likewise, even those who consider religiousness a matter for regret might nevertheless support accommodation because it makes religious individuals happier. Of course, the existence of individual interests in accommodation does not by itself generate a constitutional claim. What transforms religious accommodation from a mere policy concern to a constitutional issue is the vulnerability of religion to prejudice and persecution.

Seen through the lens of protection, the Sherbert Quartet ceases to be an anomaly in the jurisprudence of religious freedom and the Constitution more generally, and stands as precedent for a more reasonable and nuanced view of the exemptions issue. In Sherbert itself, South Carolina's violation of norms sounding in protection was transparent, and was an explicit and important element in the Court's opinion. Ms. Sherbert was a Sabbatarian, whose unavailability for work on Saturdays was treated by the state as making her ineligible for the receipt of unemployment

60 Smith, 394 US at 893-95 (O'Connor concurring); id at 908-09 (Blackmun dissenting).

61 Id at 883-84. 
benefits. But South Carolina had a Sunday closing law, so that mainstream religious believers were not put to the painful choice between fidelity to the commands of their religion and eligibility for important state benefits in hard times. Writing for the Court, Justice Brennan emphasized this disparity in circumstance:

Significantly South Carolina expressly saves the Sunday worshipper from having to make the kind of choice which we here hold infringes the Sabbatarian's religious liberty. [Justice Brennan here quoted the South Carolina statute favoring Sunday worshippers.] No question of the disqualification of a Sunday worshipper for benefits is likely to arise, since we cannot suppose that an employer will discharge him in violation of the statute. The unconstitutionality of the disqualification of the Sabbatarian is thus compounded by the religious discrimination which South Carolina's general statutory scheme necessarily effects. ${ }^{62}$

The choice of Sunday as a uniform day of rest is itself constitutionally provocative, but we are concerned now with a different point. South Carolina's election of Sunday, placed side-by-side with its refusal to accommodate the needs of Sherbert and other Sabbatarians to decline Saturday employment, gives one overwhelming reasons to suppose that the state has disadvantaged a vulnerable group.

Thomas $v$ Review Board of the Indiana Employment Security Division is less obviously a case of religious discrimination; it too, however, is best understood in this way. ${ }^{63}$ Thomas was a Jehovah's Witness who worked in a foundry of a large munitions company. When he was transferred from the foundry to a department that manufactured turrets for tanks, his religious scruples made it impossible for him to continue, and he resigned. Indiana refused to pay him unemployment benefits, on the ground that he had resigned his job without good cause. Unlike Sherbert, in Thomas there was no facial disparity in the treatment of mainstream and minority religious beliefs. But like all the unemployment benefits cases, Thomas involved a state administrative hearing and an individuated judgment that Thomas's religious

62 Sherbert, 374 US at 406. By saying that the Sunday exception "compound[s]" South Carolina's constitutional delict, Justice Brennan suggests that a constitutional problem would exist even absent the statute's express favoritism. We believe that this transparent favoritism strengthens the underlying constitutional claim, but-as our analysis of Thomas makes clear-we agree that it is not essential to Sherbert's constitutional argument.

63450 US 707 (1981). 
scruples did not constitute "good cause" for his resignation. Here there is good reason to suppose that Thomas's nonmainstream religious reason for quitting his job was inappropriately devalued as against other nonreligious and religious reasons. It is hard to imagine, for example, that Thomas would have been refused benefits had he resigned because of a serious allergy to the metal used in tank turrets; yet Thomas did have a serious allergy, a moral allergy to the job he was being asked to perform. It is also hard to imagine that if Thomas had been an orthodox Jew who was transferred to the pork-tasting division of the large company where he worked that Indiana would have found a lack of good cause in his refusal to continue. ${ }^{64} \mathrm{~A}$ state that puts in place a discretionary process to assess reasons for quitting work, and then turns a deaf ear to adherence to religious commandments as good cause, opens itself to the conclusion that it is not giving equal regard to the deep religious commitments of nonmainstream religious believers. ${ }^{65}$

The two remaining cases in the Sherbert Quartet-Hobbie $v$ Unemployment Appeals Commission ${ }^{66}$ and Frazee $v$ Illinois Department of Employment Security ${ }^{67}$ - fit this analysis nicely. Like Sherbert and Thomas, Hobbie and Frazee arose after state administrative officials refused to recognize a religious objection as "good cause" for quitting a job. In Hobbie, the Court held that it did not matter that the claimant's obligation resulted from a recent change in her religious views. ${ }^{68}$ In Frazee, the Court held that the claimant was entitled to the benefits of Thomas even though his religious views were independent of any sect. ${ }^{69}$ Both

64 It seems clear from Indiana case law that a medically verifiable, job-specific harm would constitute good cause for quitting a job. Two interesting precedents are Long $v$ Review Board, 150 Ind App 516, 276 NE2d 881 (2d Div 1971) (alleged psychic and physical harms resulting from workplace harassment did not constitute good cause for quitting because the harms had not been medically verifiable), and Dormeyer Industries $v$ Review Board, 133 Ind App 500, 183 NE2d 351 (1st Div 1962) (religious harassment of Catholic worker deemed good cause for quitting). See also Geckler v Review Board, 244 Ind 473, 193 NE2d 357 (1963) (emotional distress resulting from employment relationship did not constitute good cause for quitting where the distress was a consequence of "purely personal and subjective" elements of the employee's psyche). In our brief survey of Indiana case law, Dormeyer was the only pre-Thomas benefits case that applied the "good cause" standard to reasons related in any way to the employee's religious beliefs.

65 Of course, the state might also inappropriately devalue other, secular reasons that would justify an employee's decision to quit a job. For a discussion of other claimants who might successfully invoke constitutional norms sounding in protection, see Section IV.C.

68480 US 136 (1987).

67489 US 829 (1989).

6s 480 US at 144.

69489 US at 834. 
results flow naturally from the logic of protection: neither conversion nor idiosyncracy renders a religious interest less fundamental to the believer or less vulnerable to prejudice.

To those who have become accustomed to the idea that Sherbert carves out a preferred place for religion, our reinterpretation of these cases may be surprising. The argument is not unprecedented, however. Indeed, important elements of it have figured prominently in the opinions of some Supreme Court justices. In United States $v$ Lee, Justice Stevens observed that treating a "religious objection to the new job requirements as though it were tantamount to a physical impairment that made it impossible for the employee to continue to work under the changed circumstances could be viewed as a protection against unequal treatment rather than a grant of favored treatment for the members of the religious sect." 70 And in Bowen $v$ Roy, Chief Justice Burger's plurality opinion distinguished Sherbert and Thomas on the ground that where a state has "created a mechanism for individualized exemptions[,] . . . its refusal to extend an exemption to an instance of religious hardship suggests a discriminatory intent."."1

We should note in passing that protection also explains the result in Thornton $v$ Caldor, Inc. ${ }^{72}$ a case that, viewed from the standpoint of privilege, might seem out of harmony with the Sherbert Quartet. Connecticut passed a law requiring all employers to permit their religious employees to take their day of worship off from work. Caldor, Inc., which had refused to let Thornton off work on Sundays, challenged the constitutionality of Connecticut's accommodation. The Court sided with Caldor. If the Sherbert Quartet were about privileging religion, this result might seem hard to fathom. Connecticut may have singled out a religious observance for favorable treatment when compared to secular practices, but that legislative preference seems unobjectionable from a constitutional perspective if the Constitution itself privileges religion. ${ }^{73}$ When we change perspective from

${ }^{70} 455$ US 252, 263-64 n 3 (1982) (Stevens concurring). In Hobbie, Justice Stevens concurred on the ground that Florida had regarded "religious claims less favorably than other claims" so that Court intervention was "necessary to protect religious observers against unequal treatment." 480 US at 148, quoting Bowen $v$ Roy, 476 US 693, 707 n 17 (1986) (Stevens, concurring in part and concurring in the result).

71476 US at 708.

72472 US 703 (1985).

${ }^{73}$ Even those sympathetic to the privileging of religion might condemn the Connecticut statute for other reasons-if, for example, they thought the statute impermissibly discriminated among religions by singling out a practice (the Sabbath) important to some 
privilege to protection, the picture rapidly clears. Connecticut's statute, unlike the Court's rule in Sherbert and Thomas, does single out religious believers for a distinct accommodation. Many people have "good cause" for taking particular days off; only religious believers are protected against dismissal. The Sherbert Quartet is thus consistent with the Establishment Clause theory successfully pursued by Caldor. ${ }^{74}$

The protection rationale can fully explain the unique results in the Sherbert line of cases. It can also explain the robust use of the compelling state interest test in those cases: when we explore protection in more detail below, we will encounter good reason to regard that test as apt to Sherbert and certain other religion cases, but not well-suited to exemption cases in general. For the moment, though, we are concerned only to demonstrate that one can be sympathetic to the Court's general treatment of the unemployment benefits cases without embracing the privileging of religion.

\section{The Protection of Minority Belief as a Rationale For RELIGIOUS EXEMPTIONS}

\section{A. A New Approach: Equal Regard}

We advocate a new approach to religious exemptions, founded on protection rather than privilege. Protection can explain and justify the distinct status of religion in our constitutional tradition, offer a workable and attractive approach to religious exemptions, and-surprisingly-make some sense out of the patchwork of precedent regarding religious exemptions.

History provides ample evidence that religious distinctions inspire the worst sorts of political oppression. Post-Reformation religious strife and the religious persecution from which many

religions but not others. The Thornton Court, however, did not treat the Connecticut statute as an instance of discrimination among religions; it held the statute unconstitutional because it subordinated secular interests to religious interests. See id at 709 ("The State ... commands that Sabbath religious concerns automatically control over all secular interests at the workplace; the statute takes no account of the convenience or interests of the employer or those of other employees who do not observe a Sabbath.").

74 Of course, Caldor's Establishment Clause argument might fail for other reasons. Like another famous Connecticut statute, the law in Thornton strikes us as uncommonly silly." Griswold v Connecticut, 381 US 479, 527 (1965) (Stewart dissenting). It puts an especially unfair burden upon small employers. Whether it also exceeds the legislature's constitutional discretion to accommodate religious interests is less obvious. For preliminary reflections on related issues raised by the Religious Freedom Restoration Act, see text accompanying notes 122-35. 
colonial settlers fled come immediately to our minds. But we should not imagine that we need to look that far; within the memory of many adults, anti-Catholicism and anti-Semitism were rampant in many parts of the United States. The sad history of religious intolerance and the unfortunate sociological truths upon which it rests invite and demand the constitutional protection of minority religious beliefs.

In place of the mistaken claim that religion is uniquely valued by the Constitution, an approach based on protection depends upon the special vulnerability of minority religious beliefs to hostility or indifference. Where privilege sponsored the principle of unimpaired flourishing, protection offers the principle of equal regard. Equal regard requires simply that government treat the deep, religiously inspired concerns of minority religious believers with the same regard as that enjoyed by the deep concerns of citizens generally.

Equal regard needs to be on the active agenda of the judiciary because of the confluence of two circumstances. First, for many religious believers, being able to conform their conduct to the dictates of their beliefs is a matter of deep concern. Second, the religious provenance of these strong behavioral impulses makes them highly vulnerable to discrimination by official decision makers. Both of these propositions are widely acknowledged and do not require detailed support here. But the second bears elaboration.

Religious commandments are not necessarily founded on or limited by reasons accessible to nonbelievers; often they are understood to depend on fiat or covenant and to implicate forces or beings beyond human challenge or comprehension. Religion is often the hub of tightly knit communities, whose habits, rituals, and values are deeply alien to outsiders. At best, this is likely to produce a chronic interfaith "tone deafness," in which the persons of one faith do not easily empathize with the concerns of persons in other faiths. At worst, it may produce hostility, even murderous hatred, among different religious groups.

The axis of antagonism-even with its broad range from indifference to hostility-does not fully capture the subtle pattern of religious vulnerability. From the perspective of some faiths, it is desirable to convert nonbelievers rather than to injure them. Such messianic faiths may have the welfare of the nonbelievers genuinely and fully in mind as they zealously seek converts to the true faith; they may even have the welfare of the nonbelievers fully in mind as they seek to shape the legal regime to dis- 
courage or prevent the nonbelievers from pursuing their own beliefs. Even when conversion is not their aim, dominant faiths (or clusters of faiths) that recognize the value and concerns of others may nevertheless use political power to favor themselves. For example, Christians might seek to benefit their faith by prescribing prayers in public schools or by shutting down businesses on Sundays. Proponents might regard these partisan favors as rewards for the virtuous or as inducements to nonbelievers-or simply as nondiscriminatory benefits available to all wise enough to recognize the propriety of the Christian way of life.

These nonantagonist variations may be "kinder, gentler" forms of discrimination, but they remain stark failures of equal regard. The possibility of nonantagonistic disregard of minority concerns makes religious discrimination particularly subtle and complex. This will be important to bear in mind as we turn to the task of sketching a jurisprudence of equal regard.

\section{B. The General Methodology of a Jurisprudence of Equal Regard}

As we shall see, the complexity of religious discrimination calls forth a somewhat complex jurisprudential project in the name of equal regard. One conclusion, however, is easily drawn. Wherever else it may lead, equal regard prohibits the state from singling out the practices of minority religions for distinct and disfavored treatment. Cases like Church of the Lukumi Babalu Aye $v$ City of Hialeah ${ }^{75}$ are thus easy under an equal regard regime. The Hialeah statute's obvious failure of the equal regard test explains why the same Court that divided deeply in Smith could readily find the Hialeah statute-which by its terms targeted the ritual slaughter of animals-unconstitutional. But the transparency of the Hialeah case should not mislead us into thinking that more opaque failures of equal regard are somehow acceptable. When the state fails-whether through hate, habit, a misguided impulse to lead others to the true way, or an indifference born of a lack of empathy-to treat the deep concerns of minority believers with the same solicitude as those of mainstream citizens, the judiciary ought to intervene. The problem is crafting a constitutional jurisprudence that is suited to this task.

Let us consider the general pattern of claims for religious exemptions where the law is not overtly or facially hostile to a

7s 113 S Ct 2217 (1993) (holding unconstitutional a statute forbidding ritual animal sacrifice that amounted to suppression of Santeria practitioners' religious beliefs). 
particular religious faith. Such claims can arise in many circumstances, but two recurring prototypes are instructive. In the first, the state has a law of general application in place, but has carved out exemptions for those able to claim personal hardship or some other particularized qualification. These special exemption statutes include laws that designate formal categories of beneficiaries and others that invoke functional categories. An example of a formal special exemption is a law prohibiting the consumption of alcohol but permitting the sacramental ingestion of wine; an example of a functional special exemption is the requirement of "good cause" in unemployment compensation regimes for persons who are unable to accept or continue in a particular job.

In the second prototype for constitutional claims, the challenged state law has no provision for exemptions. It is easy to find examples of this flat rule type: the familiar peyote ban in Smith is one.

Equal regard requires that the state treat the deep, religiously inspired concerns of minority religious believers with the same regard as that enjoyed by the deep concerns of citizens generally. In either a special exemption or a flat rule case, the equal regard exemption claimant must demonstrate (a) that a general law significantly interferes with some actions motivated by her deep religious commitment; and (b) that had her deep, religiously inspired ${ }^{76}$ concerns been treated with the same regard as that enjoyed by the fundamental concerns of citizens generally, she would have been exempted from the reach of the general law. Proposition (b), in turn, can be supported by one of two claims. Either (1) the state has failed to appreciate the gravity of her interest in complying with the commands of her faith; or (2) the state has appreciated the gravity of her interest, but nevertheless has played favorites among different belief systems on sectarian grounds. Each of these last charges requires some elaboration.

To appreciate the gravity of a religious believer's interest in complying with the commands of her faith, the state must adopt the perspective of the believer; it is not at liberty to judge that interest. Equal regard bars the state from disparaging religious

${ }^{76}$ Because equal regard does not depend upon the idea that religious interests are constitutionally privileged, equal regard also protects secular claimants threatened by religious discrimination. For discussion of the issues involved, see the problem of "Secular Thomas" at text accompanying note 90 . 
interests that seem unreasonable from a secular perspective. So, for example, the state may not defend its refusal to accommodate a religious interest in animal sacrifice by arguing that it is silly or disgusting for people to take a deep interest in slaughtering chickens.

This establishes a limited kind of deference to religious perspectives. The state is further obliged to defer to the perspective of a religious believer with regard to the existence of an interest of great weight within the life of a believer. The state is obliged to treat these deep interests as equal in importance and dignity to the deep religious or secular interests of other persons. The state is not obliged, however, to accept a religious believer's judgment about the importance of her religious interests as compared to the legitimate secular interests of the state. This distinction is crucial to the idea of equal regard: outside religion, the deep interests of individuals figure into but do not override the secular concerns of the state, as we saw with Vincent the artist, whose artistic passions could not override environmental or drug laws. Equal regard insists on parity for religious belief, not privilege. If religious believers could enforce their priorities over the secular concerns of the state, we would be back to unimpaired flourishing in all of its unacceptable extremity.

The state's obligation to avoid sectarian favoritism among the holders of different belief systems bars it from preferring the deep interests of persons of one faith over those of another. The state cannot act on the perception that one faith is true, ennobling, attractive, or somehow congenial, or that another faith is false, debasing, repulsive, or somehow uncongenial. As with the obligation of the state to appreciate the gravity of a religious believer's interests, however, the obligation to avoid favoritism does not prevent the state from acting on its secular interests. So a decision, for example, to bar the importation of a particular animal on the grounds that it is a notorious carrier of a dangerous disease, does not suffer from the vice of favoritism, even though a particular faith regards the animal as sacred and an important part of its religious ceremonies.

To this point, we have been describing the conceptual entailments of equal regard, entailments that address both special exemption and flat rule cases. We now need to explore more concrete, hands-on judicial approaches to religious exemption claims. Here the difference between flat rule and special exemption cases becomes important. 
We can begin with special exemption cases and the curious status of Sherbert and its progeny. Equal regard offers a principled basis for a distinction the Court has long since backed into but has not fully elaborated; namely, the distinction between flat rule cases like Smith, and special exemption cases, at least functional special exemption cases, like Sherbert.

State unemployment benefit regimes understandably require that persons be available for work in order to qualify. Inevitably, cases will arise in which putative beneficiaries are unable to accept or continue in a particular job because of special circumstances. Our earlier example of a worker who develops a nasty allergy to the material she must handle in her job is apt here. So each state, we can imagine, must develop a mechanism for determining whether a disabling circumstance is weighty enough to justify the worker's refusal to accept or continue in a job, yet narrow enough to leave the applicant generally available for work. ${ }^{77}$

Now, we know this about the facts in Sherbert and its progeny: the applicants in each of these cases (in three of the cases the applicant observed the Saturday Sabbath, and in one the applicant took himself to be religiously barred from manufacturing munitions) fit the general profile of persons who would be approved for benefits under administrative regimes of the sort we have sketched. That is, they were generally available for work, they had powerful reasons to decline particular jobs, and the range of employment opportunities they had to decline was comparatively narrow. Under these circumstances-even without the added fact in Sherbert that the state had made extraordinary accommodation of Sunday observers-it seems perfectly appropriate to worry that ad hoc administrative refusals to treat such religiously motivated applicants as entitled to unemployment benefits represent a failure of equal regard. It also seems appropriate to protect against such failures by applying the compelling state interest test.

The unemployment benefits cases are not unique in this respect. Not terribly long ago, Jewish synagogues and Catholic churches were often denied planning permission in Protestant suburbs. We can well expect that Muslims, some orthodox Jewish groups, and various other sects will encounter comparable difficulties in locating places of worship and schools. The processing

77 If the latter condition is not satisfied, of course, the applicant may be eligible for other welfare entitlements, but not unemployment benefits. 
of applications for special use permits and other comparable interactions between municipalities and nonmainstream religious groups may well lend themselves to the Sherbert approach. ${ }^{78}$

In all the cases just discussed, the state has defined a functional exemption category: the exemption is available to claimants who meet certain requirements (in the unemployment cases, persons generally available for work but unable to take a particular job for personal reasons; in the zoning cases, noncommercial educational and civic institutions with a reason for wishing to build in a residential neighborhood). ${ }^{79}$ In principle, the exemption embraces religious interests along with secular ones. Once we know that a particular claimant fits the relevant profile but has nevertheless been denied accommodation, we may appropriately insist that the state prove that it has honored the principle of equal regard.

Matters are even simpler if a religious claimant demands the benefit of a formal, rather than functional, exemption. At best, the formal category would be a proxy for an unarticulated functional category. At worst, the category would reflect an objectionable discrimination like that rejected by the Santeria case. ${ }^{80}$ If, for example, a state liquor control ordinance were to exempt the sacramental use of liquor by some sects but not others, the Constitution would require generalizing the exemption.

Less easy to resolve are flat rule cases, of which Smith is a good example. In Smith, Oregon's prohibition on the use of peyote was a flat ban, applicable to everyone; there was no exemption procedure and hence no profile of circumstance that presumptively qualified for exemption. The question posed by equal regard is

${ }_{78}$ Constitutional battles over zoning exemptions for churches wishing to build in residential areas have been a rich source of state court litigation. In New York, for example, numerous decisions have protected churches by invalidating zoning decisions adverse to them. See, for example, Diocese of Rochester $v$ Planning Board, 1 NY2d 508, 154 NYS2d 849 (1956) (invalidating a local refusal to grant a special permit for construction of a church in a residential neighborhood); Westchester Reform Temple $v$ Brown, 22 NY 488, 293 NYS2d 297 (1968) (invalidating local land-use decision restricting use of church property); First Westminster Presbyterian Church v City Council, 57 A2d 556, 393 NYS2d 180 (Sup Ct App Div 1977) (same). We are indebted to William E. Nelson's important ongoing study of New York state law in the twentieth century, which first alerted us to this line of cases.

79 Zoning ordinances will, of course, vary with locale. For a discussion of the relevant issues, see Robert M. Anderson, 3 American Law of Zoning $\S 19.28$ at 367 (Law Co-op, 3d ed 1986) (discussing the role of "special exceptions" in land use planning).

${ }^{80}$ See text accompanying note 75. See also Larson $v$ Valente, 456 US 228, 244 (1982) ("The clearest command of the Establishment Clause is that one religious denomination cannot be officially preferred over another."). 
whether the state's refusal to accommodate the sacramental needs of the Native American Church represented ${ }^{81}$ a failure to take the deep interests of the members of the church as seriously as well-recognized secular interests or the interests of adherents to mainstream religions. The question can be posed counterfactually: if strong secular needs (medical uses, for example) or mainstream religious needs had required exception to the peyote ban, would Oregon have made such exceptions? ${ }^{82}$

The compelling state interest test, especially in the demanding form it takes elsewhere in constitutional law, is poorly suited to the job of answering this question. To be sure, the test in its normal form can function as an effective filter for failures of equal regard; by insisting that the state grant religious exemptions except when doing so would compromise interests of "the highest order," we require the state to weigh religious interests very highly. But our earlier observations about the unworkability of the equal-flourishing approach suggest that serious application of the compelling state interest test would be far too fine a filter, one which distorts civil order in unrecognizable and normatively unattractive ways. $^{83}$

A more satisfying judicial implementation of equal regard depends upon making local comparisons designed to measure the

81 We use the past tense because the Oregon legislature ultimately responded to the events surrounding the Smith litigation by revising state law to permit the sacramental ingestion of peyote. See Or Rev Stat $\$ 475.992(5)$ (1993).

${ }_{82}$ The counterfactual question asks about mainstream religions, not majority religions. We may assume that majorities would always legislate in ways consistent with their own interests, religious or not. Often, no question about exemptions for majority religions will arise, since the majority will not enact any general rule inconsistent with its own interests-though that is not necessarily the case, of course. Christian majorities, for example, may wish to prohibit the consumption of alcohol in any quantity and then exempt sacramental wine from the scope of their ban.

The counterfactual we propose assumes that the exemption question remains alive. We assume the existence of a majority willing to bind itself by the general rule, and then ask what exceptions the majority will make in favor of individuals with different interests. The point of the counterfactual is to rid the example of the distorting effects of prejudice and indifference, not to suggest that minority religions should get the distributive benefits that flow from majoritarian political power.

${ }_{83}$ McConnell takes a contrary view. See McConnell, $57 \mathrm{U}$ Chi L Rev at 1135-36 (cited in note 16) (arguing that the compelling state interest test is the only way to determine whether disparate schemes of accommodation are discriminatory). The instrumentalneutrality argument adopted by McConnell in the passage just cited seems to us different from the arguments he invokes elsewhere when he argues not simply that government must accommodate religions evenhandedly, but that government must accommodate religions to the maximum extent possible. See, for example, note 31 (discussing another argument McConnell makes on behalf of the compelling state interest test). We reject both of McConnell's strategies, but for different reasons. 
degree of accommodation implicit in the statutory scheme as a whole. Justice Stevens's analysis in Bowen $v R_{0 y}{ }^{84}$ exemplifies this strategy. Roy argued that she would violate religious convictions if she wrote her social security number on an application for welfare benefits. She sought an exemption from the rule requiring her to submit the number. In his concurring opinion, Stevens called attention to exemptions that benefitted those who, because of physical disabilities or language barriers, could not themselves fill out the applications. ${ }^{85}$ Stevens concluded that the Constitution compelled the government to accommodate religious barriers along with secular ones. ${ }^{86}$ In our terminology, we would say that Stevens found that the incomplete set of exemptions represented a failure of equal regard.

Smith and like cases will require exactly this sort of a caseby-case approach, in which evidence of the failure of equal regard is laid on the table and evaluated. In Smith itself, the evidence was cloudy at best. Oregon, like many states, made exceptions to its alcohol laws for the sacramental use of wine, but the social implications of sacramental wine and sacramental peyote may be very different. Nine other states and the federal government have made exceptions for the sacramental use of peyote, however, and we are a sufficiently national culture to see in this fact some evidence that such an exception would be reasonable in Oregon as well. That reasonability, coupled with the latitude mainstream religions enjoy to consummate their sacraments, argues for finding a failure of equal regard. Smith, we believe, could have plausibly come out either way on a case-by-case equal regard inquiry.

One approach that may seem promising would be to divide cases similar to $S$ mith between those where the religiously motivated conduct for which exemption is sought plainly injures third parties, and those where the threatened harm is only to the believer herself. But there are two reasons to avoid such an approach. First, few if any of the collisions between legislative judgment and religious commandment are truly free of impact on third parties. In Yoder, Amish parents were structuring a regime of education not for themselves, but for children who had little or no say in the matter. In Smith, the Christian Science treatmentrefusal cases, or the fundamentalist rattlesnake-handling and cyanide-drinking cases, the possible burdens of addiction, inca-

${ }^{84} 476$ US at $716-23$ (Stevens concurring).

${ }^{85}$ Id at 721 .

${ }^{86}$ Id at 721-22. 
pacity, or death may be cast not merely on the individual but also on her dependents and the state itself. Second, if we think that religious believers are entitled to make for themselves the hard choices at the margin of state authority in accord with their religious beliefs, we ought to believe that persons with deep personal commitments of a nonreligious nature enjoy the same license. Otherwise, we are committing the constitutional mistake of sectarianism or partisanship.

\section{Equal Regard and the Special Case of Secular Claimants}

A special case that fits imperfectly with our analysis thus far is that of secular claims of conscience. To address that case, we need to pause a moment to give content to two very difficult terms. For our purposes, a person is in the grip of conscience when an ethical tug toward doing the right thing becomes a central, dominating feature of her motivation and self-identity. ${ }^{87}$ And, for our purposes, the line between secular and religious conscience is roughly this: religious conscience is crucially dependent on schemes of fact and value (epistemologies) that are private in the sense that they do not depend upon their conformity to generally accepted tests of truth or widely shared perceptions of value; secular conscience, in contrast, appeals to a public epistemology that depends on generally accepted tests of truth and widely shared perceptions of value.

Equal regard, of course, is a symmetrical principle, and applies to secular as well as sectarian concerns. But it does not follow that the enforcement of equal regard as it applies to secular conscience is appropriately on the agenda of the judiciary. After all, in principle, Vincent the artist is entitled to have his deep, artistically inspired concerns treated by the state with the same regard as that enjoyed by the deep concerns of citizens generally; but it does not follow that his entitlement should be judicially enforced as an element of constitutional doctrine. As a judicially enforced constitutional principle, equal regard must be justified by vulnerability to discrimination.

Although our focus thus far has been on the vulnerability of minority religious faiths to discrimination, secular beliefs that take the form of deep commitments of conscience are also distinctly vulnerable to discrimination. Our society is sufficiently religious to make the irreligious themselves targets of discrim- 
ination, either by those offended by atheism ${ }^{88}$ or by those who sympathize only with religious claims of conscience. Understandably, it is easier for some to associate a passionate conscientious commitment that is markedly out of step with general sentiments in the society-as a claim for exemption from an otherwise valid law would entail-with an eccentric religious command than with a moral claim purporting to apply to all right-thinking persons. The conscientious-objection cases from the Vietnam War era illustrate this sort of discrimination: Congress legislated an exemption that, until modified by the Supreme Court's therapeutic construction, accommodated religious pacifists but not secular ones. ${ }^{89}$

There is an additional reason for including the enforcement of equal regard toward secular commitments of conscience within the domain of judicial responsibility. Once we have placed the protection of religious conscience within that domain, the constitutional demand that diverse belief systems be treated evenhandedly makes it inappropriate for the judiciary to parse among claimants on the basis of their metaphysics. Imagine two versions of Thomas. The first involves Thomas himself, a Jehovah's Witness whose religious scruples make it impossible for him to manufacture tank turrets. The second involves "Secular Thomas," a pacifist who is in all respects identical to the real Thomas, except that his pacifism is secular in character. A constitutional jurisprudence that permitted intervention on behalf of one Thomas but not the other would be unacceptable.

While the judicial protection of conscience appropriately extends to secular as well as religious claimants, the picture changes in one important respect with the move to secular claimants. The protection of religious conscience requires that the state treat religious belief as a "black box"; for purposes of assessing the impact of a sincerely held scheme of religious belief upon the believer, the ultimate truth or the reasonability of the scheme is beyond the constitutional competence of the state. This is implicit in the requirement of equal regard that the state defer to the perspective of a religious believer as to the existence of an interest of great weight within her life; it is a function of the epistemically distinct, closed logic of religious belief.

${ }^{88}$ Not all conscientious secular claimants will be agnostic or atheistic, of course. One could believe deeply in a given faith (including quite conventional faiths), yet found one's deep commitment to pacificism on nonreligious grounds.

${ }_{89}$ See text accompanying notes $91-98$. 
With secular claims of conscience, however, the believer and the state in principle share a common epistemic foundation. For that reason, the state may legitimately reflect upon and respond to the reasonability of the secular claimant's conscientious commitments. Reasonability here speaks not so much to the plausibility of a given belief, as to the elevation of that belief to a dominant position with regard to motivation and self-identity.

The importance of this becomes clear if we consider two hypothetical cases that might arise under Indiana's unemployment compensation scheme. The first case involves "Secular Thomas," whom we met three paragraphs back. The second case involves claimants who are members of a union. After being laid off work at a factory, both Secular Thomas and the union members are offered jobs as replacement workers when their former colleagues go on strike. The union workers refuse the jobs because they believe, on secular grounds, that it would be immoral to cross the picket lines established by their friends. ${ }^{90}$ Secular Thomas refuses the job due to his conscientious objection to the production of armaments. Indiana review officers determine that "Secular Thomas" and the union sympathizers refused work without good cause. Can these claimants invoke the theory proposed here to challenge Indiana's decision?

"Secular Thomas" has the stronger case. Even those who justify military action usually do so only in the face of great anguish and regret. The idea of a just war involves high moral stakes and many imponderables. We may accordingly think it reasonable for "Secular Thomas" to build his moral life around absolute pacifist principles, even if we disagree with those principles and even if by doing so Thomas renders himself incapable of complying with certain public norms (such as those that support the defense industry). Labor law issues have, by contrast, a more economic focus and a less immediate connection to matters of life and death. The stakes are lower and the imponderables less profound. It is possible, but not likely, that we would deem union sympathy to be reasonably constitutive of moral identity in the same way that pacifism is.

This does not mean that the union workers are unreasonable to believe that they should decline to serve as strikebreakers. We, as judges or commentators, might even agree with their judgment on that score. Equal regard, however, does not guaran-

so The facts of this hypothetical are drawn from Smith Cabinet Mfg. Co. $v$ Review Board, 146 Ind App 171, 253 NE2d 274 (2d Div 1969). 
tee that citizens will be able to honor their moral, social, or political commitments without politically imposed costs (only the fantastical principle of unimpaired flourishing does that). Consider what the union workers are asking in the name of the Constitution: they are asking that the state be obliged to treat their interest in union solidarity with the same gravity as it would treat the interest, say, of a person who had a serious medical allergy to the alloy they were being asked to work with. In the general run of unemployment claimants, the Indiana review officers are required to make judgments about what constitutes "good cause." When they do so, they are necessarily making judgments about the gravity of a given interest within the life of a reasonable person within their polity.

From this perspective, the question is not whether the union workers are right about their moral obligations. The question is instead the character of the injury that reasonable workers strongly committed to union solidarity would suffer if they were to defer to society's contrary assessment of those obligations. If the state were to conclude that the quality of this injury does not rise to that of a serious medical allergy, it is not clear that a court should overturn that judgment.

The conscientious-objection cases from the Vietnam War furnish a second set of examples. Congress enacted a statute that provided an exemption for those "who by reason of their religious training and belief are conscientiously opposed to participation in war in any form." ${ }^{\text {"11 }}$ The statute defined "religious training and belief" to mean "an individual's belief in a relation to a Supreme Being involving duties superior to those arising from any human relation, but [not including] essentially political, sociological, or philosophical views or a merely personal moral code."92 In United States $v$ Seeger, the Court concluded that the exemption encompassed any "sincere and meaningful belief which occupies in the life of its possessor a place parallel to that filled by the God of those admittedly qualifying for the exemption...." years later, in Welsh $v$ United States, ${ }^{94}$ a four-Justice plurality clarified Seeger's interpretation of the statute and stressed its application to avowedly secular belief systems.

91 See United States v Seeger, 380 US 163, 164-65 (1965).

92 Id at 165, quoting the Universal Military Training and Service Act, 50 USC app $\S$ 456(j) (1958).

33 US at 176.

94 398 US 333 (1970). 
If an individual deeply and sincerely holds beliefs that are purely ethical or moral in source and content but that nevertheless impose upon him a duty of conscience to refrain from participating in any war at any time, those beliefs certainly occupy in the life of that individual "a place parallel to that filled by . . . God" in traditionally religious persons. ${ }^{95}$

Later, in Gillette $v$ United States and Negre $v$ Larsen, decided together in one opinion, the Court rejected constitutional claims made by people who had moral objections not to "war in any form" but to the specific war in Vietnam. ${ }^{96}$ Gillette involved a secular objection; Negre a religious one. ${ }^{97}$

Applying equal regard to secular claims of conscience supports the idea that the result in Seeger was constitutionally compelled, but also provides a possible basis for distinguishing between Gillette and Negre. As we have already noticed in connection with "Secular Thomas," secular convictions about pacifism may well affect self-definition in a way analogous to religious convictions. Different judgments come into play, however, for those who reject absolute versions of pacifism. Once the possibility of a just war is admitted, one must judge a specific war on grounds that are partly empirical. Moreover, one must recognize the government's responsibility to assess the legitimacy of particular wars. In the case of a secular objector, the moral calculus facing the state is, at an epistemic level, the same as the objector's own. In light of that parallel, we might think it unreasonable for secular objectors to build moral identities around distinctions that they themselves recognize as matters inviting political resolution. This argument carries less weight with re-

95 Id at 340. Seeger and Welsh rest upon a rather audacious construction of legislative history. When Congress legislated in 1948, it did so in the shadow of two circuit court cases that adopted conflicting interpretations of an existing exemption favoring religious objectors. Compare United States $v$ Kauten, 133 F2d 703, 708 (2d Cir 1943) (the exemption encompasses all conscientious objections), with Berman $v$ United States, 156 F2d 377, 380 81 (9th Cir 1946) (rejecting the Second Circuit rule and holding that only theists were entitled to the exemption). The Senate Report on the 1948 Act-which came before the Court in Seeger and Welsh-cited Berman with approval. S Rep No 1268, 80th Cong, 2d Sess 14 (1948). See Welsh, 398 US at 348-50 (Harlan concurring) (discussing the circuit court decisions and the background against which the legislation was passed). Justice Harlan, who signed onto the Seeger opinion, expressly recanted that statutory construction in Welsh. Id at 344 (Harlan concurring). He nevertheless provided the decisive vote for broadening the exemption to embrace secular claimants, but he did so on constitutional rather than statutory grounds. Id at 344-67.

96401 US 437 (1971).

97 Id at 439-41. 
spect to religious objectors, since the state may no more pass upon the reasonableness of religious distinctions among just and unjust wars than it may pass upon the reasonableness of religious beliefs about wearing yarmulkes or eating beef on Friday. Those who accept this line of reasoning might endorse Gillette while rejecting Negre. ${ }^{98}$ Of course, this result is not a foregone conclusion: we might ultimately decide instead that it is entirely reasonable for secular individuals to build moral identities around selective antiwar commitments. That is especially so if the secular objector's selection principles put relatively little weight on empirical issues (for example, if the objector thinks that wars are just only if fought to prohibit genocide or slavery). But such secular claims, unlike their religious counterparts, demand that we make a judgment about the reasonableness of the claimant's moral commitments before we assess the state's justification for discrepant treatment.

The openness of claims of secular conscience to a public standard of reasonableness is an important gloss on our earlier observations about Seeger and Secular Thomas. Seeger clearly was correctly decided, and it would indeed be inappropriate for a court to protect the real Thomas and not Secular Thomas. But these observations cannot be generalized to the full run of conscientious secular claimants; they are specific to the (presumably

98 In some cases, the predicament of the secular and religious objector will be constitutionally indistinguishable. The religious believer might derive from her faith a rather general proposition about just and unjust wars: thinking, for example, that the only just wars are those fought to vindicate humanitarian principles rather than economic interests. The problem of applying this principle might be no different for the religious believer than for the secular philosopher who subscribes to the same principle upon different grounds. If that were the whole story, equal regard would then demand like treatment for the religious and philosophic objectors. This conclusion seems to have special force in the case of Negre, who apparently derived from theology only a general obligation "to discriminate between 'just' and 'unjust' wars." Id at 441.

However, religious belief may determine not only the content of a believer's moral commitments, but also the centrality of those moral commitments in a believer's life. Put another way, the reasonableness of building a moral life around a particular commitment may itself vary with religious perspective even if the commitment itself does not. Negre may have implicated this problem, for Negre himself was "firmly of the view that any personal involvement in that war would contravene his conscience and 'all that [he] had been taught in [his] religious training."' Id. Society need not defer to such judgments when deciding how to balance social need against individual interests-that is, society need not agree with Negre that individuals should be free to choose for themselves whether to participate in wars. Nevertheless, when determining the gravity of the individual injuries that would occur if an exemption were denied, society must respect the religious individual's own sincerely held views about the centrality of particular practices to that individual's (religiously constituted) moral identity. That requirement is what distinguishes Gillette from Negre. 
substantial) subset of claimants whose conscientious commitments are reasonable.

\section{Equal Regard and Equal Protection}

As we flesh out the idea of equal regard, it may seem to resemble a robust jurisprudence of equal protection. Robust in this sense: contemporary equal protection doctrine protects African Americans and women by barring both facial distinctions disfavoring those groups and facially neutral governmental action that is motivated by animus toward those groups; it does not bar facially neutral governmental action that has only a disparate impact on protected groups. ${ }^{99}$ Equal regard seems more demanding in this respect than equal protection, and our readers may wonder whether we mean to argue that religion should enjoy special protection, that the Supreme Court has erred in excluding disparate impact from close constitutional scrutiny in equal protection cases, or some third proposition not yet on the table.

Certainly equal regard and equal protection have much in common-not only because both invoke the general norm of equality, but also because, as we observed earlier, the Supreme Court's jurisprudence of racial equality is the most prominent example of the paradigm of protection in constitutional law. Moreover, as we shall see in a moment, one of our specific recommendations may well have implications outside the context of religious liberty. Nevertheless, it would be a mistake to conflate equal regard with traditional equal protection doctrine in general or with a new sensitivity to disparate impact in particular.

Extant equal protection jurisprudence assumes that governmental behavior operating to disadvantage a vulnerable group is either purposefully designed to accomplish that result or is innocent of any constitutionally cognizable harm. Equal regard, of course, condemns governmental behavior that purposefully harms a religious group; but it also identifies and condemns behavior that lies in a middle ground between purposeful discrimination and unintended disparate harm. Governmental action that betrays a failure to treat the serious concerns of minority religious believers with the same regard extended to the deep

99 See Washington v Davis, 426 US 229 (1976) (judicial review under the Equal Protection Clause prohibits only intentional discrimination). See also Personnel Administrator of Massachusetts $v$ Feeney, 442 US 256 (1979) (discriminatory intent exists only when actions were taken because of, not merely in spite of, their adverse effects upon an identifiable group). 
concerns of citizens generally is vulnerable to a distinct constitutional objection.

Consider again the facts of Thomas. The Indiana board, we may imagine, issues its negative ruling against Thomas in broad terms; they make plain that religious pacifists who decline or leave employment in the manufacture of munitions will be held to lack "good cause," and hence will forfeit their eligibility for unemployment compensation. Of course, this rule has a disparate impact on persons whose religious consciences condemn participation in the production of armaments, as compared with most workers in Indiana who are not disabled by religious scruples of this sort. But that circumstance, standing alone, does not constitute a failure of equal regard. The failure lies in the fact that Indiana recognizes other deep personal interests, like physical allergies, as "good cause" for declining or leaving employment. This is substantive discrimination, distinct from mere incidental harm, and constitutionally condemnable. The problem is not that Indiana's eligibility criteria disadvantage minority religions. The problem is that Indiana's policy is partial in the way that it defines personal interests: the state has failed to recognize a set of interests distinct to a minority religious position. This constitutional complaint, however, is not dependent upon a finding that the Indiana board disapproved of religious pacifism, or took satisfaction from the discomfort of religious pacifists-hence the middle ground.

The protection of religious minorities focuses on this middle ground for good reason. Religion does more than define the terms on which believers may satisfy their interests; it actually constitutes their interests. There is a substantial risk that governmental actors, even while bearing no animus toward minority religious believers, will ignore, undervalue, or implicitly denigrate their deep, religiously motivated concerns. ${ }^{100}$ This tendency stems from the sociological features of religion, features that we have already canvassed and that are familiar to historical and contemporary experience: the deep concerns of religious believers can differ sharply from each other and from widely shared secular concerns; systems of religious belief can rest on radically distinct epistemologies and be inaccessible to the reason and intuitions of nonbelievers; and religious believers may be tempted

100 Compare Mark Tushnet, "Of Church and State and the Supreme Court": Kurland Revisited, $1989 \mathrm{~S} \mathrm{Ct} \mathrm{Rev} \mathrm{373,} 398$ (discussing the inability of Christian Justices to project themselves into the understandings of "reasonable" non-Christians). 
to celebrate or reward their own faith, even while filled with loving concern for the souls of nonbelievers. As a result, the interests of religious believers may be invisible, or may appear as mere tastes or even as delusions, from the standpoint of outside observers.

The constitutional principle of equal regard bears a special relationship to programs of discretionary accommodation. Such programs, like the principle of equal regard itself, recognize and respond to idiosyncratic interests within society. Governments often choose to sacrifice general policy concerns to accommodate the deep, constitutive interests of individuals. But these discretionary schemes of accommodation may trigger the requirements of equal regard and so generate additional, constitutionally compelled exemptions.

Of course, while discretionary exemptions serve important individual interests, they also may impose substantial social costs. Accordingly, they are grudging and exceptional events rather than familiar and systematic ones. Embodied in legislation, these accommodations often take the form of an unexamined patchwork. Oregon's controlled substance laws, which exempted the ritual use of alcohol but not the ritual use of peyote, illustrate the disparities that arise. Delegating the project of accommodation to an administrative agency invites ad hoc decisions; here, Thomas is once again exemplary. This discretionary terrain is fertile ground for the undervaluation of minority religious interests.

This confluence of religious insularity, deep personal interest, and governmental discretion is what justifies and requires constitutional sensitivity to the middle ground of equal regard. We do not mean to insist, however, that the case for equal regard is innocent of implications for the reform of equal protection doctrine. To the contrary, in at least one respect our analysis leads to the identification of shortcomings in that doctrine, and there may be others.

We have suggested that the compelling state interest test may have a legitimate role to play with regard to administrative processes of the sort involved in Thomas. In that setting, the test guards against the possibility that ad hoc administrative decisions will traduce the principle of equal regard by denying benefits to religiously motivated persons who are otherwise qualified. Indeed, in a sense, cases like Thomas do not involve a claim for an exemption at all; on the contrary, Thomas and other claimants demand the fair application of a general standard-such as 
"good cause"-that they believe already fits their own circumstances. In terms of the typology we developed earlier, Thomas presents a challenge to an exemption defined functionally, not formally. Where minority religious claimants satisfy the general envelope of circumstance contemplated by an administrative regime of exemption-here, by being generally available for work and having a narrow but sharp personal interest in declining particular employment-the compelling state interest test seems well-suited to insuring that the process takes fair account of their interests.

The administration of "good cause" exemptions in unemployment compensation regimes is a ready example of how our analysis of equal regard can inform equal protection analysis outside the domain of religious claimants. Given the unique concerns of pregnant women and the social practices that usually render women responsible for child care, women have job selection interests not shared by men; and it is entirely possible that state administrators' unemployment decisions will chronically undervalue the weight or sincerity of these interests. ${ }^{101}$ That being so, it may well be the case that constitutional justice would best be served by heightened judicial scrutiny of adverse "good cause" determinations implicating pregnancy and child care. But in Arlington Heights $v$ Metropolitan Housing Corp. ${ }^{102}$ the Supreme Court applied Washington $v$ Davis to an administrative zoning process, holding that no claim of unconstitutional race discrimination could succeed absent evidence of discriminatory intent. The Court made clear that disparate impact alone would almost never constitute sufficient grounds for inferring discriminatory intent. ${ }^{103}$ Presumably, the Court would apply these prin-

101 At least prior to the Supreme Court's decision in Thomas, a disproportionate number of the Indiana unemployment benefits cases rejecting colorable claims of "good cause" involved working mothers who quit their jobs after changes in schedule, location, or home life created logistical difficulties. See, for example, Gray v Dobbs House, Inc., 171 Ind App 444, 357 NE2d 900 (2d Dist 1976) (shift change created child care problem); Ingress-Plastene, Inc. $v$ Review Board, 143 Ind App 95, 238 NE2d 490 (2d Dist 1968) (same); Wicker v Review Board, 173 Ind App 657, 365 NE2d 787 (2d Dist 1977) (female employee faced with new transportation costs); Tobin $v$ Review Board, 157 Ind App 610, 301 NE2d 404 (3d Dist 1973) (transportation problem getting to new plant); Nordhoff $v$ Review Board, 130 Ind App 172, 162 NE2d 717 (2d Div 1959) (new mother left job due to long commute). Prior to 1971 , the Indiana statute explicitly stated that parental obligations could never constitute good cause for quitting a job. Gray, $357 \mathrm{NE2d}$ at 906 . See also the harassment cases mentioned in note 64 , both of which involved female claimants.

102429 US 252, 264-68 (1977).

${ }_{103}$ Id at 266 ("Absent a pattern as stark as that in Gomillion [v Lightfoot, 364 US 339 (1960)] or Yick Wo [v Hopkins, 118 US 356 (1886)], impact alone is not determinative, and 
ciples even more resolutely to the claims of women regarding pregnancy and child care..$^{104}$

Our argument implies that, in at least this limited respect, Arlington Heights is inconsistent with Thomas. Further, there may be other administrative settings where the distinct interests of racial minorities are at hazard to a failure of equal regard. To the extent that Arlington Heights forecloses the application of the middle-ground jurisprudence of equal regard in such cases, ${ }^{105}$ we believe that it is in error. Outside these specialized administrative settings, however, the controversial rule of Washington $v$ Davis stands or falls upon considerations independent of those discussed here. ${ }^{106}$

\section{E. Congress to the Rescue?}

\section{Legislative help in securing equal regard.}

The principle of unimpaired flourishing, as we have seen, describes an unobtainable and undesirable world, and offers neither conceptual nor practical guidance for making the compromises necessary to reach an appropriate degree of accommodation for religious interests. Equal regard is very different. It is normatively attractive, conceptually precise, and describes a liveable world: a world that accommodates the deep, religiously inspired concerns of minority religious believers to the same degree as the deep concerns of citizens generally.

But equal regard is very demanding in the kind of judgment it requires; so demanding that it is unrealistic to expect the constitutional judiciary to effectively police the requirement in all cases. There will, of course, be easy cases, like Lukumi Babalu Aye ${ }^{107}$ where governmental behavior reeked of overt hostility to the beliefs and practices of the Santeria faithful. But overt hostility to religious minorities is not necessary to finding a failure of equal regard. Ultimately, equal regard constrains outcomes, not

the Court must look to other evidence.").

104 Not only has the Court applied the Davis rule to gender discrimination, see Feeney, 442 US at 273-74, but the Court has also ruled that discrimination related to pregnancy is not gender discrimination at all. Geduldig $v$ Aiello, 417 US 484, 496-97 n 20 (1974).

${ }_{105}$ Although the Arlington Heights Court did not explicitly address arguments that would counsel against applying Davis to administrative settings, its holding implicitly rejects any such limits on the discriminatory intent requirement.

${ }^{106}$ For a different view, see Stephen L. Carter, The Resurrection of Religious Freedom?, 107 Harv L Rev 118, 128-30 (1993) (arguing that Smith and Davis are wrong for the same reason).

107 113 S Ct 2217 (1993). 
processes. It is no defense if legislators give lip service to notions of religious equality, or hold extensive hearings about the interests of religious interests, or make warm, sympathetic statements about minority religions and the First Amendment; neither the trappings of good intention nor even good intentions themselves suffice. Equal regard tests the balance of concern; it demands that the government accord the religious interests of minority believers the regard they give other deep concerns, religious and secular.

In some cases, where local comparisons are available, equal regard will invite a tractable judicial inquiry. The invidious distinction between Sunday observers and Saturday observers in Sherbert is blatant because the affected interests resemble one another so closely. As comparisons grow more remote, the confidence and competence of the judiciary will begin to falter. Thomas is harder than Sherbert because the comparison requires judgments spanning a greater variety of factors than were involved in Sherbert. Likewise, it is possible, though certainly not easy, for judges in Smith to estimate the relative weight of Oregon's interest in preventing the abuse of peyote by comparison to Oregon's interest in preventing the abuse of alcohol. It would be considerably more difficult to compare the absence of a peyote exemption to exemptions pertaining to still more remote topics, such as, for example, a statutory provision exempting religiously operated day-care centers from a state's licensing scheme. ${ }^{108}$ The state interests involved are clearly different; saying which is weightier turns upon a rather stark policy judgment not readily made by judges. Somewhere along the line, the capacity of the judiciary to police equal regard will run out.

These limits, however, are related to institutional competence, not to the substance of equal regard itself. Remote discrimination may be more difficult to identify, but certainly is no more permissible, than local discrimination. For that reason, the rights that flow from equal regard are likely to be underenforced by the judiciary: the judicial regime we recommend will vindicate equal regard incompletely, and therefore legislative attention will be indispensable to full satisfaction of the principle.

Lyng $v$ Northwest Indian Cemetery Protective Ass' $n^{109}$ illustrates the institutional issues. Lyng arose because the govern-

${ }^{108}$ See, for example, Ind Code Ann $\S 12-17.4-2-7$ (West 1994) (exempting church-run facilities from child care regulations).

${ }^{109} 485$ US 439 (1988). 
ment owned land deemed sacred by a Native American religion. The Bureau of Land Management had decided to build a road through the land. Members of the religion sued, claiming that the road would desecrate the site and radically impair their ability to exercise their religion. The Supreme Court denied the claim. ${ }^{110}$ How would it fare under the regime proposed here?

Local comparisons are unlikely to yield grounds sufficient to bar the government from building its road. The common law presumed that parcels of property were largely incomparable. ${ }^{111}$ One need not go that far in order to recognize that geographic differences will vastly alter the nature and weight of government interests in developing property that it owns. ${ }^{112}$ Moreover, it is entirely possible that the key circumstance in Lyng-namely, government ownership of a sacred site-will rarely if ever recur. The comparative enterprise sponsored by equal regard may accordingly find no purchase in Lyng.

The facts of Lyng, however, are genuinely extreme. The government's choice of location for the road was going to cripple, if not destroy, an entire religious group's ability to practice their faith. ${ }^{113}$ Facts this extreme may facilitate counterfactual speculation by the judiciary about whether it was imaginable that the agency would have inflicted a comparable harm on, say, a more familiar Christian sect for no better reason than the convenience of this particular location of their road. ${ }^{114}$ The facts in Lyng could have sustained such an inquiry, and one might reasonably think the case wrongly decided on that ground.

But many cases may be like Lyng in that they offer no plausible basis for direct comparison of regard, while differing from Lyng in that they are not so extreme as to offer the possibility of a confident counterfactual speculation. This does not mean that the challenged governmental decisions refusing to accommodate religious interests reflect the evenhandedness demanded by equal

t10 Id at 458.

"11 See, for example, E. Allan Farnsworth, 3 Farnsworth on Contracts $\S 12.6$ at 172 (Little, Brown, 1990) (discussing the uniqueness presumption as grounds for favoring specific performance as a remedy for breach of real estate contracts).

112 See Lyng, 485 US at 443.

113 Id at 442 .

114 Compare id at 454 ("Except for abandoning its project entirely, and thereby leaving two existing segments of road to dead-end in the middle of a National Forest, it is difficult to see how the Government could have been more solicitous."), with id at 463-64 (Brennan dissenting) (summarizing district court findings to the effect that the proposed road served little purpose that could not be accomplished equally as well by construction at alternative locations). 
regard; it merely means that the limits of the judiciary's role to enforce equal regard has been reached. But to say that such failures of equal regard will go uncorrected by the judiciary is not to say that the failure should, or even that it will, go uncorrected. Lyng itself proves the point: in the end the political process responded to interests the judiciary had not protected, and the Bureau of Land Management relocated the road. ${ }^{115}$

In this respect, Lyng is anything but rare. When the Supreme Court refused to excuse Mennonite petitioners from participating in the social security system, Congress accommodated churches that had religious objections to participating in the social security system. ${ }^{116}$ When the Supreme Court refused to invalidate military regulations that prohibited the wearing of a yarmulke, Congress granted relief. ${ }^{117}$ And when the Supreme Court refused to exempt Native American believers from Oregon's state law prohibiting consumption of peyote, Oregon legislated an exemption to its law. ${ }^{118}$ Add to this line of decisions the Supreme Court's remarkable approval of Sunday closing laws ${ }^{119}$ and it begins to appear that the political branches have protected religious liberty more vigorously than has the Court.

There are several reasons why legislatures may be better at both the general task of accommodating religious interests and the more specific task of vindicating the constitutional principle of equal regard. With regard to accommodation in general, the explanation for legislative primacy immediately emerges from our analysis. Even if the demands of equal regard have been fully satisfied, legislatures have discretion to enhance the value they place upon accommodating fundamental personal commitments, including religious commitments. The legislature's decision favoring increased accommodation would not be a matter of

115 See House Committee on Appropriations, Department of the Interior and Related Agencies Appropriations Bill, 1989, HR Rep No 713, 100th Cong, 2d Sess 72 (1988) (withdrawing funding for the road).

116 Compare United States $v$ Lee, 455 US 252 (1982) (denying relief), with 26 USC \& 3121(w) (1984) (exempting from Social Security obligations those "churches and churchcontrolled organizations" that are "opposed for religious reasons to the payment of the tax imposed under Section 311"). The relief granted by Congress would not, however, help Lee himself, for he was not operating a "church-controlled organization."

11 Compare Goldman $v$ Weinberger, 475 US 503 (1986) (denying relief), with 10 USC $\S 774$ (1988) (granting it).

118 Compare Smith, 494 US 872 (denying relief), with Or Rev Stat $\S 475.992(5)$ (1993) (granting it).

${ }_{119}$ See Braunfeld v Brown, 366 US 599 (1961) (rejecting Free Exercise challenge); McGowan v Maryland, 366 US 420 (1961) (rejecting Establishment Clause challenge). 
constitutional duty, although the principle of equal regard would then require the legislature (and authorize the courts) to ensure that the new premium upon accommodation is shared equally.

When it comes to applying equal regard, legislators again have an advantage over judges. Judges must make local comparisons to test whether legislators have fairly weighed individual interests against the interests of the public as a whole. Legislators, however, need not rely upon local comparisons. They may judge the weight of government interests directly, and thereby compare them even across widely disparate policies. Global comparisons depend upon difficult judgments about the importance of various government interests, but such judgments are, after all, integral to everyday legislative decision making.

It may seem odd to rely upon the political branches to bring the enforcement of equal regard up to full measure. Isn't this an especially bold case of inviting the fox to guard the chickens? After all, the need for a judicially enforceable constitutional principle of equal regard stems from the fact that elected officials will often violate it because of religious bias. And, indeed, we do believe that this concern about bias makes it impossible for the judiciary to abandon responsibility for exemption claims entirely, as the Smith majority seemed willing to do.

The institutional dynamic is, however, complicated for two reasons. First, political institutions do not speak with one voice. Religious bias may be most likely to prevail in small policy-making bodies that work in poorly lit corners of the public square. The individual claims officers involved in Thomas provide an extreme example of discretion that is both relatively unarticulated and concentrated in a single individual. Less extreme versions of the same problem may arise with respect to decision making by bureaucracies, small towns, military commanders, and legislative committees. But as Madison pointed out in Federalist 10, we have reason to expect better from more cosmopolitan institutions, especially Congress as a whole. ${ }^{120}$

Second, political institutions may react differently to an issue once they see it as a matter of religious liberty. Some may, as one would hope, take the time and care to research the impact of legislation upon religious freedom. Legislators are, however, always busy and sometimes sloppy. Constitutional issues are not generally their chief preoccupation. ${ }^{121}$ They may accordingly

${ }^{120}$ Federalist 10 (Madison), in Clinton Rossiter, ed, The Federalist Papers 82-83 (Mentor, 1961).

${ }_{121}$ Compare Sager, 65 NYU L Rev at 958 (cited in note 40) (Unlike the legislature, the 
pass legislation without recognizing the constitutional questions it poses. Cases like Goldman, Lyng, and Smith thus serve an important "signalling" function by alerting legislative defenders of religious liberty to an issue that may have escaped their attention. Litigation under the principle of equal regard would continue to serve that function, even if (as happened in Goldman, Lyng, and $S$ mith) the courts themselves refused relief.

2. The unhappy case of the Religious Freedom Restoration Act of 1993.

Legislative solicitude for religious liberty does not always aid the constitutional cause, of course. The Religious Freedom Restoration Act of 1993 is a glaring case in point. A sweeping repudiation of Smith, the Act instructs courts to grant individuals exemptions from laws that substantially burden their "exercise of religion," except where "application of the burden to the person (1) is in furtherance of a compelling governmental interest; and (2) is the least restrictive means of furthering that compelling governmental interest."122 As evidence that the elected branches may be counted upon to support religious liberty vigorously, the Act is exemplary. As policy, however, the Act is certainly unwise and perhaps unconstitutional. It is a clumsy and misguided response to the failings of Smith.

The compelling state interest test is suitable only where it is appropriate to indulge in a broad and robust presumption of unconstitutionality, where the great run of cases that present the characteristic that triggers the test will be abhorrent to our best understanding of appropriate governmental behavior. As we have been at pains to demonstrate, religious exemption cases do not fit that description. Conscientious governments, acting for sound, unbiased reasons, will nevertheless promulgate general rules that interfere with some religious beliefs; the prolixity and idiosyncracy of religious belief make such collisions inevitable. This is openly conceded by all fair commentators, and no one seriously advances the claim that secular government must routinely yield to the full run of religious commandments. To mandate the compelling state interest test under these circumstances is to invite

judiciary introduces into the political process "an interval of review keyed exclusively ... to questions of political justice.").

122 Pub L No 103-141, 107 Stat $1488,1488-89$, § 3 (1993), codified at 42 USCA $\S$ $2000 \mathrm{bb}-1$. 
confusion, duplicity, and dilution. That is the unmistakable lesson of our experience with religious exemptions before Smith.

There is little indication that Congress gave the unhappy pre-Smith experience serious thought. Indeed, it is unlikely that Congress understood that the results in the Sherbert line and in Yoder were the exception rather than the rule even before Smith, that in the jurisprudence of religious accommodation the compelling state interest test has been "strict in theory but feeble in fact," or that the pre-Smith accommodation jurisprudence as a whole was laced with confusion and contradiction. This is doubly unfortunate. It is doubtful that an informed Congress would have cast the Act in such problematic terms. And now that Congress has done so, it falls upon the judiciary to give meaning to a doctrinal formulation that failed for good reason once before. Should the Religious Freedom Restoration Act be read to "restore" the status quo ante, with all of its fluttering uncertainty? Should the triggering condition of the statute-namely, the imposition of a "burden" on "a person's exercise of religion"-be understood to refer to the constitutional concept of Free Exercise (which could, in turn, be understood to refer to a concern for equal regard rather than undiminished welfare), or some independent concept? Should the statute's compelling state interest language be understood as invoking the pale pre-Smith use of that standard in religion cases, as referring to more robust and stable applications of the standard in other constitutional areas, or as inviting the Court to make a fresh start in the religious accommodation area, guided by the words of the standard detached from any of the their familiar environments? ${ }^{223}$

In the course of sowing this confusion, the Act forfeits whatever benefits might accrue from special legislative competence. Instead of evaluating specific claims for exemption, Congress simply handed the problem back to the judiciary, inviting it to continue on its erratic pre-Smith course. If Congress wished to improve the federal government's sensitivity to religious interests, it could have done much better. Congress could, for example, have constituted a subcommittee with special responsibility for identifying instances in which religious interests had been

${ }^{123}$ For similar reflections, see, for example, Marci A. Hamilton, The Belief/Conduct Paradigm in the Supreme Court's Free Exercise Jurisprudence: A Theological Account of the Failure to Protect Religious Conduct, 54 Ohio St L J 713, 753-54 n 240 (1993) (arguing the plan of the Act is "plainly self-contradictory"); Note, $78 \mathrm{Va} \mathrm{L} \mathrm{Rev} \mathrm{at} \mathrm{1439-40} \mathrm{(cited} \mathrm{in}$ note 16) (claiming the Act "accomplish[es] little" and may hinder efforts to secure legislative accommodation). 
undervalued by state or federal actors designing general policies. Congress might then have remedied these specific problems by tailoring legislation to protect the religious interests at stake. Such a process would have drawn upon congressional competence, diminished litigation costs, and avoided embroiling the judiciary in the awkward way mandated by the Act.

Legislation is not unconstitutional simply because it is badly drafted or misguided. In this instance, however, the Act's defects raise serious constitutional questions. Congress seems to have believed that those seeking exemptions for religiously motivated conduct were constitutionally entitled to the benefits of the compelling state interest test, both in principle and as a matter of pre-Smith precedent. This was the situation Congress sought to "restore." But Congress was mistaken both about constitutional principle and about the best understanding of pre-Smith decisions. The resulting divergence between the best constitutional understanding and the pseudoconstitutional mandate of the Religious Freedom Restoration Act raises several problems. ${ }^{124}$

First, the Act may be outside the scope of congressional power. Insofar as it affects state law, the Act purports to draw its authority from Section 5 of the Fourteenth Amendment. Most theories of Section 5 authority limit its scope to legislation that vindicates constitutional rights; on these accounts, Congress can go further than the judiciary in protecting constitutional rights, but only because the judiciary does not or cannot fully protect such rights. Such limits, when combined with the constitutional argument of this essay, draw into question the Act's constitutionality: equal regard does not generally entitle those claiming religious exemptions to the presumptive force of the compelling state interest test, and hence Section 5 may not authorize Congress to impose the compelling state interest standard upon the states.

Second, in its attempt to re-inflate pre-Smith jurisprudence, the Act may itself be unconstitutional under the equal regard standard. Equal regard calls upon courts to guard against policies that disfavor fundamental secular commitments by comparison to religious interests. The Religious Freedom Restoration Act explicitly protects only those interests which are religious. If the statute's reference to religion is interpreted restrictively and exclusively, the resulting favoritism for religion is probably unconstitutional. ${ }^{125}$

${ }^{124}$ Ira Lupu has expressed doubts similar to those raised by the two articles in note 123. See Lupu, $140 \mathrm{U} \mathrm{Pa} \mathrm{L} \mathrm{Rev} \mathrm{at} \mathrm{609-10} \mathrm{(1991)} \mathrm{(cited} \mathrm{in} \mathrm{note} \mathrm{16).}$

${ }^{25}$ Compare Thornton v Caldor, Inc., 472 US 703 (1985) (holding unconstitutional a 
The third constitutional problem of the Religious Freedom Restoration Act is more subtle but perhaps more damning than the other two. The Act deploys a conceptual vocabulary that is abidingly constitutional. The Act begins by articulating findings that criticize the Court's constitutional judgment in Smith. ${ }^{226}$ The articulated purpose of the Act is "to restore the compelling state interest test as set forth in [Sherbert and Yoder] ...."127 The Act uses the language of constitutional doctrine to name the delict that is its target: governmental behavior that "substantially burden[s] a person's exercise of religion ...." ${ }^{228}$ And the Act directs courts to measure exceptional claims for justification of that delict against a constitutional standard, the compelling state interest test. ${ }^{129}$ The Act directs the Court to play a peculiar part in a constitutional drama: the Court must act as though it had changed its mind about the constitutional status of religious exemptions, or as though it were obliged to accept Congress's judgment about the meaning of the Constitution as decisive.

Rather than simply legislating to protect religious interests, Congress has represented its policy as a correction to the internal logic of a doctrine for which the judiciary has principle responsibility. In effect, the Act seeks to compel the courts to adjudicate apparently constitutional claims in a manner inconsistent with the Supreme Court's own judgment about the Constitution. By masking the character of Congress's action, the constitutional formulations of the Religious Freedom Restoration Act diminish

Connecticut statute that required employers to permit religious employees to stay home from work without fear of dismissal on their religiously determined day of rest).

${ }^{126} 42$ USCA $\S 2000 \mathrm{bb}(\mathrm{a})$ reads:

Findings.-The Congress finds that-

(1) the framers of the Constitution, recognizing free exercise of religion as an unalienable right, secured its protection in the First Amendment to the Constitution;

(2) laws "neutral" toward religion may burden religious exercise as surely as laws intended to interfere with religious exercise;

(3) governments should not substantially burden religious exercise without compelling justification;

(4) in Employment Division v. Smith, 494 U.S. 872 (1990) the Supreme Court virtually eliminated the requirement that the government justify burdens on religious exercise imposed by laws neutral toward religion; and

(5) the compelling interest test as set forth in prior Federal court rulings is a workable test for striking sensible balances between religious liberty and competing prior governmental interests.

${ }^{127}$ Id $\S 2000 \mathrm{bb}(\mathrm{b})$.

${ }_{128}$ Id $\S 2000 \mathrm{bb}-1(\mathrm{a})$.

I29 Id § 2000bb-1(b). 
institutional accountability and detract from the educative impact of constitutional adjudication. ${ }^{130}$

As such, the Act may be an especially troubling example of what the Court condemned in United States $v$ Klein. ${ }^{131}$ In Klein, the Court considered a congressional statute enabling Union loyalists to recover property that had been seized from them during the Civil War. In order to prohibit recovery by persons whose claim to loyalty depended upon a presidential pardon, Congress instructed the Court of Claims to dismiss such claims for want of jurisdiction. The Klein Court found the antipardon provision unconstitutional on two alternative grounds. First, the provision infringed upon the presidential pardon power. Second, the provision created a "rule of decision" in "cases pending before" the court; that is, "the court is forbidden to give the effect to evidence which, in its own judgment, such evidence should have, and is directed to give it an effect precisely contrary." ${ }^{\prime 32}$ It is this second proposition that connects Klein to the Religious Freedom Restoration Act. The Klein Court's argument is not easy to decipher, but the Court seems to have been insisting that Congress cannot enlist the judiciary in a charade, requiring it to apply a given statutory standard in a manner fundamentally different than it thought proper. ${ }^{133}$ Nowhere should we be more sympathetic with this constitutional objection to legislative overreaching than when the charade implicates the content of important constitutional principles like religious liberty. ${ }^{134}$

The Act might survive each of these challenges. For example, some theories of the Fourteenth Amendment construe Section 5 to authorize any legislation that expands the scope of individual liberty. Or supporters of the Act might pin their hopes on the almost limitless pliancy of the modern Commerce Clause. As for the substantive challenge, perhaps the courts would be willing to offer a therapeutic construction of the sort propounded in Seeger, where imaginative interpretation allowed secular claimants to share the benefits of a statute that, by its terms, applied only to

${ }^{130}$ On the Court's educative role, see generally Christopher L. Eisgruber, Is the Supreme Court an Educative Institution?, 67 NYU L Rev 961 (1992) (analyzing that role).

13180 US 128 (1871).

132 Id at 146-48.

${ }^{133}$ See Lawrence Gene Sager, Foreward: Constitutional Limitations on Congress' Authority to Regulate the Jurisdiction of the Federal Courts, 95 Harv L Rev 17, 70-77, 87-88 (1981) (discussing Klein).

${ }^{134}$ Another illustration of this principle is New York $v$ United States, 112 S Ct 2408 (1992), where the Court held that Congress cannot mask national policy behind state policy by commanding the states to perform specific actions. 
those moved by "religious training and belief" and "belief in relation to a Supreme Being."135 Finally, defenders of the Act might distinguish Klein by relying on a formal point: the provision challenged in Klein was an instruction addressed to courts, while the Religious Freedom Restoration Act imposes substantive regulations on nonjudicial actors.

For the moment, we prefer to remain agnostic about these issues. Much will inevitably turn upon judicial interpretation of the Act. The ambiguities of the congressional "restoration" make it possible that judges will construe the Act through the lens of equal regard. That seems to us the best course. By pursuing it, courts would not only avoid the constitutional difficulties identified above but also lend new coherence to a doctrine sorely in need of principled reconstruction.

\section{F. The Autonomy of Religious Organizations}

Principles of protection can, we believe, supply a powerful and attractive basis for constitutional rights exempting religiously motivated conduct from generally applicable laws. The vulnerability of religion, not its virtue or precedence, seems to us the foundation for the Constitution's special solicitude for religious activity. Yet, having journeyed so doggedly in one direction, it now seems appropriate to tack in another. Protection and privilege are not mutually exclusive competitors. What we have said at least twice before bears repeating: religious conduct will often draw to its aid principles of privilege not limited to religion. If we neglect that point, the limits upon equal regard will begin to seem puzzling. We are now in a position, for example, to see how privilege and protection provide overlapping forms of constitutional security for religious organizations.

We begin by summarizing and elaborating some points made earlier. The idea that the government may not tell churches how to choose their leaders or regulate their membership has secular analogues: the government may not tell us whom we may invite to our home, how we should choose our friends, or what rules should govern conversation at the dinner table. Constitutional theorists often treat this set of rights by reference to ideas about privacy; our suggestion is that we should understand privacy in a way that embraces the life of religious communities. This approach would fail if activities ceased to be private whenever they 
involved large numbers of people, took place outside the home, or encompassed formal behavior. But such characteristics need not control our understanding of the public/private distinction. Instead, we propose that some relationships project private behavior into public spaces. On this view, the public or private character of an association would depend in part upon its purposes. Some goals-such as intimacy, shared understanding, self-expression, personal growth, and philosophical edification-tend to put associations and conduct on the private side of the line. Other objectives-especially commercial prosperity and political power-provide grounds for regarding associations and conduct as public. The differences among these various purposes make it sensible (although not always easy) to distinguish among those associations that constitute communities, and hence have a private aspect, and those which seem instead to be mere public organizations.

That some large associations (religious or not) may have essentially private aspects should come as no surprise to those familiar with Supreme Court jurisprudence. In his opinion for the Court in Roberts $v$ United States Jaycees, Justice Brennan suggested the existence of a "broad range of human relationships" arrayed between two "poles": at the level of greatest privacy, "the selection of one's spouse," and at the level of least privacy, "the choice of one's fellow employees." According to Brennan, diverse factors will play a role in placing a given relationship within this spectrum. He pointed in particular to "size, purpose, policies, selectivity, congeniality, and other characteristics that in a particular case may be pertinent." ${ }^{\text {"137 While }}$ Brennan's interpretation allows for the possibility that family relationships and activities within the home may enjoy special constitutional solicitude, it specifically acknowledges that private association may also occur apart from home and family. Indeed, only after determining that the "Jaycees are large and basically unselective groups" and that "the Jaycees [have] failed to demonstrate that the Act imposes any serious burdens on [their] freedom of expressive association" did the Roberts Court hold that Minnesota's antidiscrimination law was constitutional as applied to that group. ${ }^{138}$ The extended conception of privacy respected by the Court's analysis in Roberts provides what is in our view

138 Id at $621,626$. 
the cornerstone of constitutional security for church autonomy. ${ }^{139}$

Thus far, we are in the domain of privilege untouched by concerns about protection and equal regard. As we begin to explore more nuanced issues of church autonomy, however, we will find it necessary to analyze them in terms of both privilege and protection. Churches are often complex and powerful organizations. In addition to choosing members and leaders, they will likely engage in economic activity and may sponsor a variety of institutions, from hospitals to universities to health clubs. The privacy-based rationale for church autonomy does not afford equal protection to all these aspects of organized religious activity. On the one hand, for example, decisions about membership and leadership will enjoy full protection. These actions are closely analogous to more personal choices about guests and friends. Absent a guarantee of autonomy vigorous enough to protect the integrity of such decisions, true communities-be they religious or companionate-cannot come into being.

On the other hand, when churches offer services and products for sale, their revenues and their decisions about wages and prices will be subject to the full range of state economic regulation. Commercial transactions, we suggested earlier, are a quintessentially public mode of interaction. When churches enter the commercial arena, they take advantage of a market made possible by the government and specifically entrusted to its care. Thus, the privacy-based rationale for institutional autonomy provides no reason to exempt religious manufacturers from the minimum wage laws. ${ }^{140}$ Nor does it supply any reason to protect religious merchants from the obligation to collect a sales tax in connection with the merchandise they sell. ${ }^{141}$

That does not end the constitutional analysis, of course. It is precisely at this juncture that equal regard comes to bear upon church autonomy. The religious manufacturer and religious vendor may still make a constitutional claim for exemptions by invoking the local comparisons sponsored by the principle of equal

139 Ira Lupu also treats Roberts as crucial to issues of church autonomy, but he construes the resulting right much more narrowly than do we. See Lupu, 67 BU L Rev at 433-38 (cited in note 15) (recommending that churches be free to restrict their membership and to deny employment to nonmembers).

140 The Supreme Court so held in Alamo Foundation v Secretary of Labor, 471 US 290, 304-05 (1985).

111 The Supreme Court reached this conclusion in Jimmy Swaggart Ministries $v$ Board of Equalization, 493 US 378 (1990). 
regard. But they, unlike the church seeking the freedom to discriminate when choosing its leaders, must depend upon equal regard because privacy principles do not encompass commercial claims.

Between these extremes lie a number of more difficult cases. A church that runs a university or a health club may deny access to some people for religious reasons-either by restricting participation to church members, or by excluding those nonmembers who do not conform to theological dictates. Is this analogous to controlling membership in the church itself? Or is it best regarded as just another facet of church-run commercial activity (assuming that the church charges recipients for the services it provides) subject to general state regulation? Reasonable people will differ about how to answer these hard questions. A number of case-specific distinctions may be important. We might wish to know, for example, whether the religiously run facilities are intended to turn a profit and, in the case of religiously run universities, whether the curriculum is pervasively sectarian. If we take our cues from Supreme Court precedent, it would appear that even in the case of a sectarian university, where one might think the interest in community especially vigorous, the religious institution is entitled only to discretionary accommodation (subject, of course, to the constraints of equal regard). ${ }^{142}$

Cases restricting religious control over the design of church buildings raise another set of difficult questions. For example, does the government intrude upon private matters of religious community when it invokes landmark legislation to prohibit a church from moving its altar? ${ }^{143}$ One might reasonably think that it does: the regulation seems constitutionally suspect for the same reason that we might recoil from a law controlling the bedroom furniture in an architecturally significant family residence. Homes and churches lose their character as such if control over internal design is wrested from the communities-familial or religious-that inhabit them.

142 This principle seems implicit in the Supreme Court's decision in Bob Jones University $v$ United States, 461 US 574, 602-04 (1983) (concluding the government's interest in achieving racial equality outweighs the burdens that result from denial of tax benefits). Denying tax benefits to institutions that discriminate is, of course, a less severe measure than prohibiting them from discriminating entirely; nevertheless, under the theory we propose, it would be clearly unconstitutional for the government to condition the taxexempt status of churches upon their willingness to select priests without regard to race or gender.

${ }_{143}$ See, for example, Society of Jesus v Boston Landmarks Commission, 409 Mass 38, 564 NE2d 571 (1990) (granting relief pursuant to the Massachusetts state constitution). 


\section{CONCLUSION}

Cast in the mold of constitutional privilege, the idea of religious liberty is self-contradictory. The problem is not simply that religious liberty at its margins may conflict with other constitutional precepts, or even that under the umbrella of religious liberty we may find subsidiary principles that are at times in conflict. The problem is deeper than either of these familiar observations. At its core, religious liberty is about the toleration-the celebration-of the divergent ways that members of our society come to understand the foundational coordinates of a well-formed life. To single out one of the ways that persons come to understand what is important in life, and grant those who choose that way a license to disregard legal norms that the rest of us are obliged to obey, is to defeat rather than fulfill our commitment to toleration. Yet that favoritism is precisely what the privileging view of religious liberty requires.

Yet, if the defects of the privileging view are patent, so too are the conditions that make constitutional solicitude for religion essential. Religious persecution drove many of the settlers of the colonies from Europe to America and drove some from their newfound homes in America. Religious discrimination is not merely an artifact of constitutional history. Within the memory of many adults, it was a prominent feature of our national landscape, and it would be far too optimistic to think that we have outgrown the human impulse to respond badly to the basic differences of culture, habit, and belief that attach to diverse religious faiths. So while the root infirmity of conferring constitutional privilege on religious belief has been sufficiently well understood to curb the Court's enthusiasm for such a privilege, the impulse to preserve nonmainstream religious belief from hostile or indifferent governmental treatment has had a durable-and deserved-place in constitutional adjudication. The resulting tension has made a hash of the jurisprudence of religious accommodation.

The problem lies not with religious liberty but with the paradigm of constitutional privilege and with the principle of unimpaired flourishing that paradigm sponsors. If we replace privilege with protection and replace unimpaired flourishing with equal regard, we can rebuild the jurisprudence of religious accommodation. We can make sense of what has seemed scattered precedent, and we can make religious liberty compatible with its own roots in toleration-and hence with the whole of our tradition of constitutional liberty. 
$$
\text { . }
$$ 